\title{
1 Autophagy Compensates for Lkb1 Loss to Maintain Adult Mice Homeostasis and Survival
}

2 Khoosheh Khayati ${ }^{1}$, Vrushank Bhatt ${ }^{1}$, Zhixian Sherrie $\mathrm{Hu}^{1}$, Sajid Fahumy ${ }^{1}$, Xuefei Luo ${ }^{1}$, Jessie

3 Yanxiang Guo $1,2,3, \#$

$4 \quad{ }^{1}$ Rutgers Cancer Institute of New Jersey, New Brunswick, New Jersey 08901, USA

5 '2Department of Medicine, Rutgers Robert Wood Johnson Medical School, New Brunswick, New

6 Jersey 08901, USA

7 3 Department of Chemical Biology, Rutgers Ernest Mario School of Pharmacy, Piscataway, New

8 Jersey 08854 , USA

9 \# Corresponding Author

Running title: Autophagy and Lkb1 in Adult Mice Homeostasis

Keywords: autophagy, Atg7, Lkb1, p53, intestinal epithelium barrier, host homeostasis

Financial supports:

NIH P30 CA072720 to Rutgers Cancer Institute of New Jersey

Corresponding Author:

Jessie Yanxiang Guo, Ph.D.

Rutgers Cancer Institute of New Jersey

RBHS-Robert Wood Johnson Medical School

Rutgers, The State University of New Jersey

195 Little Albany Street

New Brunswick, NJ 08901

yanxiang@cinj.rutgers.edu

Voice: 732-235-9657

\section{Potential Conflicts of Interest}

We have no conflict of interest to declare. 


\section{Abstract}

2 Liver Kinase B1 (LKB1) is the major energy sensor for cells to respond to metabolic stress.

3 Autophagy degrades and recycles proteins, macromolecules, and organelles for cells to survive

4 starvation. To access the role and cross-talk between autophagy and Lkb1 in normal tissue

5 homeostasis, we generated genetically engineered mouse models where we can conditionally

6 delete $L k b 1$ and autophagy essential gene, Atg7, respectively or simultaneously, throughout the

7 adult mice. We found that Lkb1 was essential for the survival of adult mice, and autophagy

8 activation could temporarily compensate for the acute loss of Lkb1 and extend mouse life span.

9 We further found that acute deletion of Lkb1 in adult mice led to impaired intestinal barrier function,

10 hypoglycemia, and abnormal serum metabolism, which was partly rescued by the Lkb1 loss-

11 induced autophagy upregulation via inhibiting p53 induction. Taken together, we demonstrated

12 that autophagy and Lkb1 work synergistically to maintain adult mouse homeostasis and survival.

Abbreviations: LKB1: liver kinase B1; AMPK: 5' adenosine monophosphate-activated protein kinase; mTORC1: mammalian target of rapamycin complex1; PJS: Peutz-Jeghers syndrome; ATG7: autophagy related7 gene; TCA: tricarboxylic acid; TAM: tamoxifen; UBC: ubiquitously expressed ubiquitin C; LC3: light chain3; TAK1: transforming growth factor beta-activated kinase1 (TAK1); HCQ: hydroxychloroquine; WT: wild type; H\&E: hematoxylin and eosin; IHC:

20 immunohistochemistry; OLFM4: olfactomedin4; FITC: Fluorescein Isothiocyanate; CDKN1A:

21 cyclin-dependent kinase inhibitor 1A; PTEN: phosphatase and tensin homolog. 


\section{Introduction}

2 Liver kinase B1 (LKB1) is a tumor suppressor, metabolic sensor and master modulator of AMP-

3 activated protein kinase (AMPK) and mammalian target of rapamycin complex1 (mTORC1)

4 activity, leading to the control of energy metabolism, cell polarity, cell survival and proliferation (1-

5 3). Heterozygous germline mutations in $L K B 1$ lead to the development of Peutz-Jeghers

6 syndrome (PJS), an autosomal dominant disease with hamartomatous polyp formation in the

7 gastrointestinal tract (4). Constitutive deficiency of Lkb1 leads to embryonic lethality due to

8 impaired neural tube closure and somitogenesis, mesenchymal tissue cell death, and defective

9 vasculature (5). Specific deletion of Lkb1 in vascular endothelial cells results in dilated embryonic

10 vessels and death at E12.5, which is attributed to the reduced $\operatorname{Tgf} \beta$ signaling in yolk sac $(1,6)$.

11 Liver-specific deficiency of Lkb1 causes impaired glucose metabolism (7). Muscle-specific

12 deletion of Lkb1 results in lower fasting blood glucose and insulin levels, along with increased

13 glucose uptake through muscles (8). Lkb1 loss in hematopoietic stem cells causes dysfunctional

14 mitochondria, leading to pancytopenia due to reduced levels of ATP, fatty acids and nucleotides

$15(3,9,10)$. Taken together, tissue-specific knockout studies underscore the importance of Lkb1 in

16 tissue homeostasis, metabolism, and stem cell maintenance. Somatic $L K B 1$ mutations are related

17 with a number of human cancers; however, tissue-specific removal of $L k b 1$ in mice does not

18 necessarily lead to tumor formation (11).

20 Autophagy, a highly conserved self-degradative process, plays an essential role in cellular stress

21 responses and survival (12-14). Yeast cells rely on autophagy to survive nitrogen starvation (15);

22 neonatal mice depend on autophagy to survive neonatal starvation-induced amino acid depletion

23 (12); and adult mice requires autophagy to survive starvation $(14,16)$.

25 Given that both Lkb1 signaling and autophagy play indispensable roles in maintaining tissue 
1 supporting homeostasis of adult mice. We engineered mice to conditionally (Tamoxifen (TAM)-

2 inducible) and systemically delete $L k b 1$ and $A t g 7$, either respectively or simultaneously. Same as

3 previous report (16), systemic Atg7 ablation led to extensive liver and muscle damage, and

4 neurodegeneration starting at 6 weeks post-deletion, and limited mouse survival to 3 months.

5 Surprisingly, we found that adult mice with acute ablation of $L k b 1$ through whole-body ( $L k b 1^{-1-}$

6 mice) died within 30 days and showed upregulated autophagy in most tissues. Moreover,

7 systemic co-deletion of $L k b 1$ and $A \operatorname{tg} 7$ limited mice survival to 20 days. $L k b 1^{-/-}$mice displayed

8 disruption of intestinal structure and impaired intestinal defense barrier, which was deteriorated

9 by co-deletion with Atg7. Supplementation of broad-spectrum antibiotics or systemic deletion of

$10 p 53$ partly rescued the death of the mice with concurrent deletions of $L k b 1$ and $\operatorname{Atg} 7$, but not the

11 mice with $L k b 1$ deletion alone. Serum metabolomics profiling analysis showed that acute short-

12 term deletion of $A \operatorname{tg} 7$ or $L k b 1$ respectively significantly decreased the levels of most essential and

13 non-essential amino acids and some metabolites involved in the tricarboxylic acid (TCA) cycle,

14 urea cycle and glycolysis. This phenotype was further enhanced in mice with concurrent deletions

15 of $A \operatorname{tg} 7$ and $L k b 1$. Taken together, this study reveals a novel role of Lkb1 in the management of

16 tissue homeostasis in adult mouse and the mechanism by which autophagy upregulation

17 temporarily compensates for the acute loss of Lkb1.

19 Results

\section{Acute systemic $\mathbf{L k b 1}$ deletion upregulates autophagy in adult mouse}

21 Tissue-specific $L k b 1$ knockout studies demonstrate that Lkb1 plays an important role in 22 supporting tissue and organ homeostasis (11). However, how Lkb1 regulates adult mouse 23 homeostasis is unknown. Autophagy is required to maintain tissue homeostasis and mouse

24 survival in starvation $(14,16)$. Whether and how Lkb1 and Atg7 interact to maintain tissue 25 homeostasis for adult mouse survival remains an open question. To address this, we generated 26 genetically engineered mouse models, in which Atg7 and $L k b 1$ were surrounded by flox alleles, 
1 whereas the expression of a TAM-regulated Cre-recombinase was manipulated through the

2 ubiquitously expressed ubiquitin C (Ubc) promoter (17). Four mouse strains were generated: Ubc-

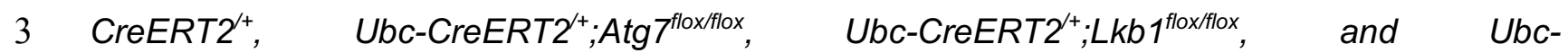

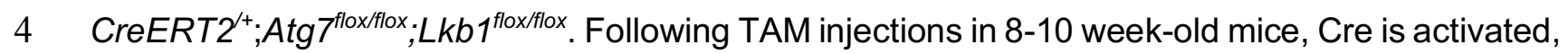

$5 \quad$ leading to the deletion of $A \operatorname{tg} 7$ or $L k b 1$, and producing a near complete and sustained loss of Atg7

6 protein $\left(A \operatorname{tg} 7^{-/-}\right.$mice), Lkb1 protein ( $L k b 1^{-/}$mice), or dual deletions of Atg7 and Lkb1 proteins

$7 \quad\left(\right.$ Atg $7^{-/} ; L k b 1^{-/-}$mice $)$in all tissues (Fig. 1a). The deletions of Lkb1 and Atg7 throughout the mouse

8 tissues were confirmed by western blot (Fig. 1b). In addition, accumulation of autophagy substrate

9 p62 was observed in all tissues of the mice with Atg7 ablation ( $\operatorname{Atg} 7^{-/-}$mice and $\operatorname{Atg} 7^{-/-} ; \operatorname{Lkb} 1^{-/-}$mice $)$

10 (Fig. 1c), indicating autophagy blockade.

12 Given that AMPK is required for autophagy activation, Lkb1 deficiency leads to the loss of AMPK

13 activity and suppression of autophagy (18). Consequently, studying the role of autophagy in the

14 mice with systemic loss of Lkb1 may be considered counterintuitive. However, studies from us

15 and other groups have shown that AMPK is activated in the mouse Kras-driven lung tumors with

16 Lkb1 loss $(19,20)$. Indeed, we also observed that autophagy is required for Kras-mutant Lkb1-

17 deficient lung tumorigenesis (19). Instead of Lkb1, AMPK can be activated by calmodulin-

18 dependent kinase kinase (CaMKK), and transforming growth factor beta-activated kinase1

19 (TAK1) $(21,22)$, further leading to autophagy activation. We therefore examined the autophagy

20 status in $L k b 1^{-/}$mice by administering the mice with hydroxychloroquine (HCQ) to block

21 autophagy flux. Accumulation of autophagy substrates including both microtubule-associated

22 protein 1A/1B- light chain3 (LC3) I and II along with p62 were observed in most tissues of mice

23 after 5 hours of HCQ treatment. Moreover, HCQ treatment led to a higher accumulation of LC3-II

24 and p62 in Lkb1-deficient mice compared with wild type (WT) control mice (Fig. 1d), indicating

25 that autophagy is activated and upregulated in the mice with acute loss of Lkb1. 


\section{Interaction of Lkb1 and autophagy is required for adult mouse survival}

2 It has previously been shown that mice with systemic autophagy ablation have a life span of 2-3

3 months and the mortality is due to initial Streptococcus infection and eventual neurodegeneration

4 (16). Whereas, adult mice with whole-body $L k b 1$ deletion survive for up to 6 weeks (23). Given

5 that both Lkb1 signaling and autophagy pathway regulate cellular homeostasis $(12,16,18,24)$,

6 we hypothesize that upregulation of autophagy in Lkb1-deficient mice might compensate for the

7 acute Lkb1 loss to maintain energy homeostasis for mouse survival. Therefore, we evaluated the

8 overall survival of adult mice with acute deletion of $A \operatorname{tg} 7$ and $L k b 1$ respectively or in combination.

9 Our data reproduced the survival rate for $\operatorname{Atg} 7$-deficient mice when $\operatorname{Atg} 7$ was acutely deleted in

10 adult mice (Fig. 2a) (16). The life span of $L k b 1$-deficient mice was limited to 4 weeks post-TAM

11 administration. Co-deletion of $\operatorname{Atg} 7$ and $L k b 1$ led to a significant decrease in the survival of $\operatorname{Atg}^{-}$

$12 \quad ; L k b 1^{-/}$mice compared with $L k b 1^{1^{-/}}$or $A \operatorname{tg} 7^{-/-}$mice, resulting in less than 3 weeks of survival (Fig.

$132 a)$.

15 At 15 days post-TAM administration, compared with WT control mice, there was a significant loss

16 of body weight in $L k b 1^{-/}$mice, which was further deteriorated by the loss of Atg7 (Fig. 2b).

17 Hematopoietic-specific $L k b 1$-deficient mice died from pancytopenia (9). We did not observe any 18 differences of red and white blood cell and platelet count among WT control, Atg $7^{-/}$, and $L \mathrm{~kb} 1^{-/-}$

19 mice; however, the platelet count in $A \operatorname{tg} 7^{-/-} ; L k b 1^{-/-}$mice was significantly higher than that in WT 20 control mice (Supplementary Fig. 1).

22 Acute autophagy ablation aggravates Lkb1-deficiency-induced loss of secretory cell 23 structure in small intestine

24 To elucidate the underlying mechanism by which Atg7 and $L k b 1$ ablation alone or in concurrent 25 impacts the mouse survival, we examined the histology of different tissues. After short-period (15 26 days) of protein deletion, which is before the death of $\operatorname{Atg} 7^{-/-} ; L k b 1^{-/-}$mice, the damage of tissues 
1 was not observed in Atg7-deficient mice (Supplementary Fig. 2a). Moreover, except for the

2 intestine (Fig. 3a), most of the tissues in both $L k b 1^{-\alpha}$ and $A \operatorname{tg} 7^{-\alpha} ; L k b 1^{-\alpha}$ mice were not visibly

3 affected as examined by hematoxylin and eosin (H\&E) staining (Supplementary Fig. 2a). Same

4 as tissue-specific $L k b 1$ deletion in intestinal-epithelium cells (25), enlarged undifferentiated

5 goblet-Paneth cells in the crypt of intestine, including duodenum, jejunum, and ileum, were

6 observed in $L k b 1^{-/-}$mice, which was further exacerbated by the concurrent ablation of Atg7 in

$7 \quad \operatorname{Atg}^{-/} ; L k b 1^{--}$mice (Fig. 3a). This observation was further confirmed by Alcian blue staining for

8 goblet cells and immunohistochemistry (IHC) for lysozyme staining to detect Paneth cells (Fig. 3b

9 and c). The decreased intensity of lysozyme staining indicates less frequent and undifferentiated

10 Paneth cells in $\operatorname{Atg}^{-/} ; L k b 1^{-/}$mice (Fig. 3c). In addition to western blot (Fig. 1b), the deletion of

11 Lkb1 and Atg7 specifically in intestine was also confirmed by IHC (Supplementary Fig. 2b). In consistent with induction of autophagy in Lkb1-deficient mice, LC3-II puncta were observed in the

13 intestine of $L k b 1^{-/-}$mice (Supplementary Fig. $2 \mathrm{c}$ ).

15 To evaluate the role of Lkb1 and autophagy in other components of the small intestinal crypt, we examined the status of stem cells that reside at the bottom of the crypt for regenerating almost all

17 the epithelium cells, including Paneth and goblet cells, enterocytes and tuft cells $(26,27)$. IHC for 18 olfactomedin4 (OLFM4) (an intestine stem cell marker) shows the lower intensity and frequency 19 of stem cells in $L k b 1^{-/}$mice compared with WT control or $A t g 7^{-/-}$mice (Fig. 3d). Moreover, co20 deletions of $L k b 1$ and $A \operatorname{tg} 7$ further reduced the intensity and frequency of the cells expressing 21 OLFM4 compared with Lkb1 deletion alone (Fig. 3d). However, short-term deletion of Atg7 alone 22 only impaired Paneth cell formation (Fig. 3c) (28).

24 The structure of the small intestine was extremely damaged by $L k b 1$ deletion alone or co25 deletions of $L k b 1$ and $A \operatorname{tg} 7$ (Fig. 3a-d), which could be due to less regeneration from intestinal 26 stem cells or increased cell death. Cell death in small intestine occurs through apoptosis at the 
1 tip of the villi which eventually leads to shedding of dead cells into the lumen $(29,30)$. We found

2 that there was a significant increase of apoptotic cell death in the tip of the villi in $\operatorname{Atg} 7^{-1-} ; L k b 1^{-1-}$

3 mice compared with $L k b 1^{-/}$mice (Fig. $3 e$ ). Intestinal crypt is the region for cell division and

4 migration to upper sites of the villi (31). Compared with the WT control mice, we did not observe

5 any significant difference in the cell proliferation rate in the crypt of the mice lacking either Atg7

6 or $L k b 1$ alone or in combination (Supplementary Fig. 2d).

8 Taken together, we show that Lkb1 is necessary for maintaining the structural integrity of the

9 intestine and that autophagy activation partly compensates for the severe intestinal phenotype

10 induced by the loss of Lkb1.

12 Autophagy activation in Lkb1-deficient mice protects the intestinal epithelium-barrier

13 function

14 Intestinal epithelium cell-specific deletion of $L k b 1$ results in an increased susceptibility to dextran

15 sodium sulfate-induced colitis and a definitive shift in the composition of the microbial population

16 in the mouse intestine (32), suggesting that Lkb1 plays an important role in maintaining the

17 immune barrier function of the intestinal epithelium. Moreover, it has recently been reported that

18 autophagy is essential for the maintenance of $\mathrm{Lgr}^{+}$stem cells and regeneration of epithelium

19 barrier during cytotoxic stress (33). We therefore examined the integrity of intestinal epithelium-

20 barrier in mice with systemic deletion of $A \operatorname{tg} 7$ or $L k b 1$ alone, or their co-deletion by measuring the

21 Fluorescein Isothiocyanate (FITC)-dextran in-fluxed from the gastrointestinal tract to peripheral

22 circulation. We observed significantly increased levels of serum FITC-dextran in Lkb1-deficient

23 mice compared with WT control mice, which is further increased by the co-deletion with Atg7 in

$24 A \operatorname{Atg} 7^{-/-} ; L k b 11^{--}$mice (Fig. 3f). However, short-term systemic ablation of $\operatorname{Atg} 7$ alone did not impair

25 intestinal epithelium-barrier (Fig. 3f). This observation suggests that upregulated autophagy by

26 acute $L k b 1$ deletion is required for the maintenance of intestinal epithelium-barrier. 
2 Loss of intestinal epithelium-barrier causes mice to be susceptible to bacterial infection (32). We

3 found that the levels of D-lyxose, an aldopentose sugar and a component of the bacterial 4 glycolipids (34), was significantly increased in $\operatorname{Atg}^{-/-} ; L k b 1^{-/-}$mice compared with WT control (Fig.

$53 \mathrm{~g}$ ), indicating defective bacterial defense. We therefore hypothesized that increased bacterial

6 infection by loss of intestinal epithelium barrier could contribute to the mouse death caused by

7 co-deletions of $L k b 1$ and Atg7. Hence, we treated the $L k b 1^{-/-}$and $A \operatorname{tg} 7^{-/-} ; L k b 1^{-/-}$mice with broad-

8 spectrum antibiotics and assessed the mouse survival rate in comparison with untreated ones.

9 Broad-spectrum antibiotics administration significantly extended the survival of $\operatorname{Atg} 7^{-/-} ; \mathrm{Lkb}^{1^{-/}}$mice

10 (Fig. 3h), whereas, did not affect the lifespan of $L k b 1^{-/}$mice (Fig. 3i). Thus, one of the potential

11 mechanisms of autophagy activation in response to acute systemic Lkb1 deficiency could be to

12 maintain the survival of mice by preventing bacterial invasion.

14 Autophagy activation in Lkb1-deficient mice prevents p53 activation to maintain mouse

15 survival

16 Given that autophagy drives an inhibitory role towards p53 activation $(12,35,36)$, we expected

17 to observe an increased p53 activation in autophagy-deficient mouse tissues. Indeed, IHC 18 staining for $\mathrm{p} 53$ showed that the frequency of nuclear p53 was significantly higher in most tissues 19 of $\operatorname{Atg}^{-/-} ; L k b 1^{-/-}$mice compared with $L k b 1^{-/-}$mice or WT control mice after short-term deletion of 20 the genes (Fig. 4a and Supplementary Fig. 3). This is also accompanied by the significantly

21 increased mRNA levels of p53-targted downstream genes such as p21 and phosphatase and 22 tensin homolog (PTEN) in $A \operatorname{tg} 7^{-/-} ; L k b 1^{-/-}$mice compared with $L k b 1^{-/-}$mice or WT control mice (Fig.

$234 b)$. Accordingly, we tested the hypothesis that activation of autophagy by acute $L k b 1$ ablation

24 could prevent mouse death by inhibiting p53 activation. To address this, two new cohorts of mice 25 were $\quad$ generated: Ubc-CreERT2 $2^{/+} ; L k b 1^{\text {flox/flox }} ; p 53^{\text {flox/flox }}, \quad$ and Ubc26 CreERT2 $2^{/+} ; A \operatorname{tg} 7^{\text {flox/flox}} ; L k b 1^{f l o x / f l o x} ; p 53^{\text {flox/flox. }}$. TAM administration can cause concurrent deletion of 
$1 \quad L k b 1$ and $p 53\left(L k b 1^{-/-} ; p 53^{-/}\right.$mice $)$or $\operatorname{Atg} 7, L k b 1$ and $p 53\left(\operatorname{Atg} 7^{-/-} ; L k b 1^{-/-} ; p 53^{-/-}\right.$mice $)$throughout the

2 whole body. We evaluated the role of $p 53$ deletion in mouse survival by comparing with $L k b 1^{-1-}$

3 mice and $\operatorname{Atg}^{-/} ; L k b 1^{--}$mice that have intact $p 53$. Systemic $p 53$ ablation had no effect on the

4 survival of $L k b 1$-deficient mice. However, whole-body ablation of $p 53$ significantly extended the

5 life span of $A \operatorname{tg} 7^{-/} ; L k b 1^{-/-}$mice (Fig. 4c). Thus, when $L k b 1$ is acutely ablated throughout the adult

6 mice, autophagy inhibits p53 activation to temporarily extend the mouse life span.

$8 \quad$ Lkb1 and Atg7 are required to maintain adult mice homeostasis

9 To further elucidate the underlying mechanism of Lkb1 and Atg7 in supporting adult mice survival,

10 we performed serum metabolomics in fasting state after short-term deletion of the genes. Of the

1190 metabolites we examined, we found that acute deletion of Atg7 or Lkb1 alone significantly

12 decreased the levels of most essential and non-essential amino acids and some metabolites

13 involved in urea cycle and glycolysis (Fig. 5a-d). Interestingly, we found that the reduced levels

14 of TCA cycle intermediates were only observed in the absence of $\operatorname{Atg} 7\left(\operatorname{Atg} 7^{-\alpha}\right.$ mice and $\operatorname{Atg} 7^{-/}$

$15 ; L k b 1^{-/}$mice), but not in $L k b 1$-deficient mice (Fig. $\left.5 b\right)$. We further found that in both fasted state

16 (Fig. 5d) and fed state (Fig. 5e), blood glucose level was significantly lower in $L k b 1^{-/}$and $A \operatorname{tg} 7^{-/-}$

$17 ; L k b 1^{-/}$mice compared with WT control mice. Following that, we evaluated the serum insulin

18 levels in all 4 groups of mice. The insulin levels in $L k b 1^{-/}$and $A \operatorname{tg} 7^{-/} ; L k b 1^{-/-}$mice were decreased

19 with the same trend as glucose compared with WT control mice (Fig. 5f), delineating the possibility

20 of pancreatic malfunction in these mice, although the damage in pancreas was not visible by

21 histology (Supplementary Fig. 2a). We also performed a metabolomics profiling analysis of the

22 intestinal tissue (ileum) that showed significantly impaired histology and function in both $L k b 1^{-1-}$

23 and $\operatorname{Atg}^{-/} ; L k b 1^{-/}$mice (Fig. 3). The alteration of metabolic pathways in the intestine

24 metabolomics profiling due to $A \operatorname{tg} 7$ and $L k b 1$ ablation was consistent with the change in the serum

25 metabolomics profiling, ie, the loss of $L k b 1$ alone or together with Atg7 ablation resulted in the

26 decreased levels of certain intermediates involved in the amino acid metabolism, TCA cycle, urea 
1 cycle and glycolysis (Supplementary Fig. 4). Thus, autophagy synergizes with Lkb1 to maintain

2 host homeostasis in the adult mice.

\section{Discussion}

5 In this study, we demonstrated the intermingled essential and systemic roles of Lkb1 and

6 autophagy in the maintenance of mouse homeostasis and survival via conditional whole-body

7 deletion of $L k b 1$ and $A \operatorname{tg} 7$ in adult mice (Fig. 6). We found that acute Lkb1 loss led to damaged

8 intestinal epithelium barrier and increased infection, and alteration in metabolic pathways

9 necessary for maintaining host homeostasis, which was partially rescued by autophagy activation

10 via inhibiting p53 induction. Thus, autophagy upregulation compensates for the acute Lkb1 loss

11 to temporarily support the survival of adult mice.

13 An accumulating body of evidence suggests that Lkb1 phosphorylates AMPK and activates

14 autophagy in response to energy crises $(1-3,18,21)$. However, in addition to Lkb1, CaMKK, and

15 TAK1 also trigger AMPK activation (22). Here we observed an upregulation of autophagy in $L k b 1$ -

16 deficient mice, suggesting that Lkb1-AMPK-mTORC1-autophagy axis may not be the only or the

17 critical effector of Lkb1-mediated maintenance of adult mice homeostasis in our setting. This is

18 consistent with a previous study that Lkb1-mediated energy metabolism is largely independent of

19 Lkb1 regulation of AMPK and mTORC1 signaling in mouse hematopoietic stem cells (9).

20 Moreover, AMPK and autophagy were activated in Lkb1-deficient lung tumors $(19,20)$.

22 Homozygous deletion of $L k b 1$ in mouse is embryo-lethal (5), demonstrating an important role of

23 Lkb1 in embryogenesis. Here, we reported an indispensable role of Lkb1 in maintaining the

24 homeostasis and survival of adult mice. Mice carrying one inactivated allele of $L k b 1\left(L k b 1^{+/-}\right)$

25 recapitulate PJS and die at 11 months after birth due to the development of intestinal polyps (37).

26 Hematopoietic stem cell-specific deletion of $L k b 1$ led to limited mouse survival for up to 28 days 
1 due to pancytopenia (9). However, in our study, although mice died within 4 weeks after $L k b 1$

2 ablation, no obvious reduction in different types of blood cells was observed. Instead, serum

3 metabolomics analysis showed significant reduction in most of the essential and non-essential

4 amino acids, certain metabolites related to the urea cycle and glycolysis in $L k b 1^{-/}$mice compared

5 with WT mice. Thus, the impaired systemic homeostasis by acute Lkb1 loss may be responsible

6 for the death of $L k b 1^{-/-}$mice.

$8 \quad$ Lkb1 is involved in the development and maintenance of the goblet and Paneth cells (25). Specific

9 deletion of $L k b 1$ in intestinal stem cells leads to increased expression of pyruvate dehydrogenase

10 kinase4 and reduced oxygen consumption, which reduces the population of stem cells and

11 increase the levels of secretory cell number (24). The impaired goblet and Paneth cells are also

12 characteristics of PJS in humans (37). Our whole-body deletion of $L k b 1$ recapitulates the intestinal

13 phenotype observed previously. Additionally, we found that the impaired intestinal structure was

14 further exaggerated when Atg7 is concurrently deleted with $L k b 1$. The major function of Goblet

15 cells is attributed to the secretion of mucus to provide the epithelium immune barrier against

16 bacterial invasion from the intestinal lumen (26). Loss of Lkb1 in intestinal-epithelium cells

17 impaired intestinal barrier function (32). Here we demonstrated that the integrity of intestinal-

18 epithelium barrier and function are damaged with a greater extent in $A \operatorname{tg} 7^{-/-} ; \angle k b 1^{-/-}$mice compared

19 with $L k b 1^{-/-}$mice, leaving the mice vulnerable to infection. We found that broad-spectrum

20 antibiotics supplementation could partially rescue the death of $A \operatorname{tg} 7^{-1-} ; L k b 1^{-/-}$mice, but not $L k b 1^{-/-}$

21 mice. Although the role of autophagy in microbial defense is well established (38-40). Here we

22 demonstrated for the first time the role of autophagy in preventing infection-related death induced

23 by Lkb1 loss.

25 p53 is activated upon autophagy deletion, leading to increased apoptotic rates in mouse liver and 26 brain, impairing the overall mouse homeostasis (36). A recent study shows that Atg7 specific 
1 deletion in $\mathrm{Lgr5}^{+}$epithelium cells promotes p53-induced apoptosis, leading to impaired integrity

2 of intestinal barrier during stress (33). Our data was in line with these recent findings, where we

3 found that whole body deletion of $p 53$ significantly rescued the survival of $\operatorname{Atg} 7^{-/} ; \operatorname{Lkb} 1^{-/}$mice.

4 Conversely, $p 53$ deletion had no effect on the life span of $L k b 1^{-/-}$mice, showing that autophagy

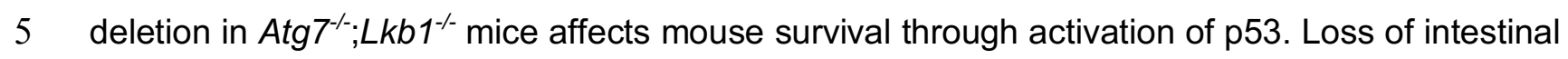

6 barrier integrity is ascribed to the imbalance between cell proliferation in the crypt and cell

7 migration towards the tip of villi where eventually cells undergo apoptosis (31). We observed

8 increased apoptotic cell death in the villus tips of intestine in $A \operatorname{tg} 7^{--/} ; L k b 1^{-1}$ mice compared with

$9 L k b 1^{-/}$mice, which could be due to $p 53$ activation in the absence of autophagy. However, the rate

10 of cell proliferation in the crypt between $\operatorname{Atg} 7^{--} ; L k b 1^{--}$and $L k b 1^{-/}$mice showed no significant

11 difference. Thus, autophagy upregulation induced by acute Lkb1 loss plays an important role in

12 maintaining a balance between cell proliferation and cell death in the intestine, presumably by

13 inhibiting p53 induction.

15 Reduction of serum glucose and insulin levels were observed in both $L k b 1^{-/}$, and $\operatorname{Atg} 7^{--} ; L k b 1^{-/}$

16 mice, indicating that abnormal pancreatic function may lead to impaired gluconeogenesis and

17 hypoglycemia. This data is also in parallel with muscle-specific $L k b 1$-deficient mice, which showed

18 decreased blood glucose and insulin levels due to increased uptake of glucose through muscles

19 (8). Most of the intermediates associated with amino acid metabolism, urea cycle, TCA cycle and

20 glycolysis were significantly decreased by acute $L k b 1$ ablation. Certain metabolites even showed

21 higher extent of reduction in $A \operatorname{tg} 7^{-/} ; L k b 1^{-/}$mice compared with $L k b 1^{-/}$mice. Moreover, the

22 changes of metabolomics profiling in the intestine is consistent with that in serum, suggesting that

23 this alteration occurs throughout the whole body, not a specific tissue. Taken together, both

24 autophagy and Lkb1 are essential to maintain the host metabolism in adult mice. 


\section{Material and Methods:}

\section{Mice}

3 All animal experiments were performed in compliance with Rutgers Animal Care and Use

4 Committee (IACUC) guidelines. Ubc-CreERT2 mice (17) (Jackson Laboratory) were cross-bred

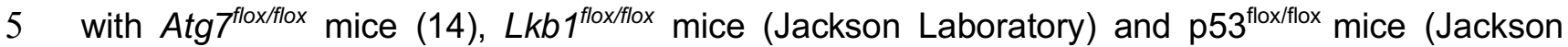

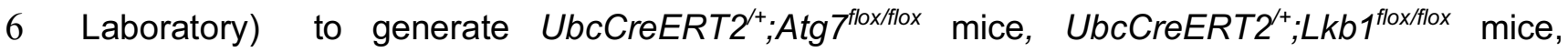

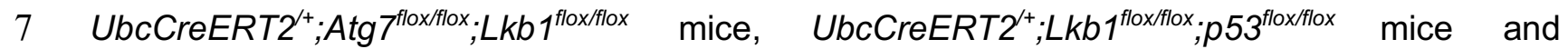
$8 \quad$ UbcCreERT2 ${ }^{\prime+} ; A \operatorname{Atg} 7^{\text {flox/flox }} ; L k b 1^{\text {flox/flox }} ; p 53^{\text {flox/flox }}$ mice.

10 For the acute deletion of $A \operatorname{tg} 7, L k b 1$ and $p 53$, TAM (200 ul of suspended solution per $20 \mathrm{~g}$ body 11 weight) was delivered to 8-10-week-old adult mice through intraperitoneal (IP) injections every 3 12 days for 4 times. In analysis of the survival curve, day 1 is the first day of TAM injection. Full 13 deletion of the genes was obtained around day 9 (post-third injection).

15 To examine autophagy flux in adult mice, $\mathrm{HCQ}$ (100 mg per $\mathrm{kg}$ ) was applied to the mice through 16 IP injection.

18 To examine the effect of broad-spectrum antibiotics on the survival of $L k b 1^{-/}$or $A \operatorname{tg} 7^{-/} ; L k b 1^{-/-}$ 19 mice, broad-spectrum antibiotics Baytril (2.27\% enrofloxacin) (5 mg per $\mathrm{kg}$ ) was injected to the 20 mice via IP twice per day.

\section{Serum assays}

23 Blood glucose was measured using a True2Go glucose meter (Nipro Diagnostics), and liquid 24 chromatography-mass spectrometry (LC-MS) metabolomics analysis (mentioned below). Serum 25 insulin levels were assessed with an ultra-sensitive mouse insulin (Crystal Chem Inc., 90080) kit. 


\section{Metabolomics analysis by LC-MS}

2 Tissue or serum metabolites extracted using methanol:acetonitrile:water (40:40:20) (with 0.5\%

3 formic acid solution for tissue metabolite extraction and without formic acid for serum metabolite

4 extraction) followed by neutralization with 15\% ammonium bicarbonate were used for LC-MS, as

5 described previously (13). Samples were subjected to reversed-phase ion-pairing

6 chromatography coupled by negative mode electrospray ionization to a stand-alone orbitrap mass

7 spectrometer (Thermo Fisher Scientific).

$9 \quad$ Intestinal permeability analysis

10 In-vivo intestinal permeability was measured by FITC-dextran (Sigma Aldrich) gavage

11 experiment. Mice were deprived from water overnight before oral gavaging with FITC-dextran at

$1244 \mathrm{mg}$ per $100 \mathrm{~g}$ body weight. Subsequently, water was provided after gavage and blood samples

13 were collected by cardiac puncture at 4 hours post-gavage. Sera were collected after centrifuging

14 blood at $10,000 \mathrm{rpm}$ for 10 minutes using $1.5 \mathrm{~mL}$ heparin-lithium coat tubes. Fluorescence

15 intensity of the serum was measured, and the concentration of FITC-dextran was assessed

16 according to the standard curve generated by the serial dilution of FITC-dextran (32).

18 Histology and immunohistochemistry

19 Paraffin-embedded tissue sections were prepared as described previously (12) for H\&E, and IHC

20 staining. Antibodies utilized for IHC were Atg7 (Sigma Aldrich, A2856), Lkb1 (Santa Cruz

21 Biotechnology, sc-32245), p62 (Enzo Life Sciences, PW9860-0100), LC3 (Nano Tools, LC3-

22 5F10), Ki67 (Abcam, ab-15580), cleaved caspase-3 (Cell Signaling, 9661S), OLFM4 (Cell

23 Signaling, 39141), lysozyme (Agilent, A0099), and p53 (Novus Biologicals, NB200-103SS). For

24 the quantification of IHC on p53 and cleaved caspase-3, tissues were analyzed by quantifying at

25 least 10 images at 20x magnification. A minimum of 200 cells were scored for each image. 


\section{$1 \quad$ Western blotting}

2 Tissues were snap-frozen in liquid nitrogen, ground using Cryomill in liquid nitrogen at $25 \mathrm{~Hz}$ for 2

3 minutes, and then lysed in Tris lysis buffer $(1 \mathrm{M}$ Tris- $\mathrm{HCl}, 1 \mathrm{M} \mathrm{NaCl}, 0.1 \mathrm{M}$ EDTA, 10\% NP40).

4 Protein concentrations were measured using the Bio-Rad BCA reagent. Samples were probed

5 with antibodies against Atg7 (Sigma Aldrich, A2856), Lkb1 (Santa Cruz Biotechnology, sc-32245),

6 LC3 (Novus Biologicals, NB600-1384), p62 (American Research Products, 03-GP62-C), and $\beta$ -

7 actin (Sigma Aldrich, A1978). Western blots were quantified with Image $\mathrm{J}$ (National Institutes of

8 Health). The intensities of bands were used to calculate relative ratios of the indicated protein

9 over loading control (actin), which were then normalized based on the corresponding ratio in the

10 wild type control sample.

\section{Real-time PCR}

13 Total RNA was isolated from the tissues using Trizol (Invitrogen). cDNA was then reverse-

14 transcribed from the total RNA using MultiScribe RT kit (Thermo Fisher). Real-time PCR was

15 performed on Applied Biosystems StepOne Plus machine. Cdkn1a (p21), PTEN and actin genes

16 were detected using predesigned commercial TaqMan primers for each gene accordingly

17 (Cdkn1a: Mm00432448-m1, PTEN: mm00477210-m1, and Actin: Mm00607939-s1). Results

18 were calculated using the $\Delta \Delta \mathrm{C}_{\mathrm{T}}$ method and then normalized to actin.

\section{Statistics}

21 Data were expressed as the mean \pm SEM. Statistical analyses were carried out with GraphPad

22 Prism version 8.0 or Microsoft Excel. Significance in the Kaplan-Meier analyses to determine and

23 compare the progression-free survival was calculated using the log-rank test. The mass spectra were analyzed by MAVEN software and the peak area of each detected metabolite was obtained.

25 Statistical significance of metabolites was determined by a paired two-tailed Student's t-test, and five mice from each genotype were used. P-value of $<0.05$ was considered statistically significant. 
1 The heatmap of amino acids was generated by using $R$ 3.6.1. program, and all values are

2 processed by the mean normalization. Pearson algorithm was used for the hierarchical clustering

3 of the rows.

5 Acknowledgments:

6 We are grateful to Dr. Eileen White for her advice during the preparation of the manuscript;

7 Wenping Wang in the Guo laboratory for helping with generation of heat map; Amy Lee, Nuha

8 Syed, Akash Raju, Jerry Kong and Enrique Lopez in the Guo laboratory for helping with mouse

9 ear tagging and genotyping. This work was supported by National Institute of Health (NIH) grant

10 R01 CA237347-01A1, NIH grant K22 CA190521, American Cancer Society grant 134036-RSG-

11 19-165-01-TBG, GO2 Foundation for Lung Cancer and the Lung Cancer Research Foundation to

12 J.Y.G; New Jersey Commission on Cancer Research (NJCCR) grant DFHS18PPC021 to K.K;

13 NJCCR grant DCHS19PPC013 to V.B; and NIH P30 CA072720 to Rutgers Cancer Institute of

14 New Jersey.

\section{Author Contributions:}

17 J.Y.G. was the leading principal investigator who conceived and supervised the project. J.Y.G.

18 and K.K. designed the experiments, interpreted the data and wrote the manuscript. K.K.

19 performed the majority of the experiments and data analysis. V.B. performed the qRT-PCR and

20 assisted with some of the survival experiments. Z.S.H. assisted with the mouse husbandry. S.F.

21 assisted with tissue metabolite extractions. X.L. assisted with mouse genotyping.

22

23 Conflict of interest: The authors declare that they have no conflict of interest.

\section{References}


1 1. Corradetti MN, Inoki K, Bardeesy N, DePinho RA, Guan KL. Regulation of the TSC pathway

2 by LKB1: evidence of a molecular link between tuberous sclerosis complex and Peutz-Jeghers

3 syndrome. Genes Dev. 2004;18(13):1533-8.

4 2. Alessi DR, Sakamoto K, Bayascas JR. LKB1-dependent signaling pathways. Annu Rev

$5 \quad$ Biochem. 2006;75:137-63.

6 3. Nakada D, Saunders TL, Morrison SJ. Lkb1 regulates cell cycle and energy metabolism in

7 haematopoietic stem cells. Nature. 2010;468(7324):653-8.

8 4. Giardiello FM, Brensinger JD, Tersmette AC, Goodman SN, Petersen GM, Booker SV, et al.

9 Very high risk of cancer in familial Peutz-Jeghers syndrome. Gastroenterology. 2000;119(6):1447-

1053.

11 5. Ylikorkala A, Rossi DJ, Korsisaari N, Luukko K, Alitalo K, Henkemeyer M, Makela TP.

12 Vascular abnormalities and deregulation of VEGF in Lkb1-deficient mice. Science. 2001;vol 293:

$13 \quad 1323-1326$.

14 6. Londesborough A, Vaahtomeri K, Tiainen M, Katajisto P, Ekman N, Vallenius T, et al. LKB1

15 in endothelial cells is required for angiogenesis and TGFbeta-mediated vascular smooth muscle

16 cell recruitment. Development. 2008;135(13):2331-8.

17 7. Zhou G, Myers R, Li Y, Chen Y, Shen X, Fenyk-Melody J, et al. Role of AMP-activated protein

18 kinase in mechanism of metformin action. Journal of Clinical Investigation. 2001;108(8):1167-74.

19 8. Koh HJ, Arnolds DE, Fujii N, Tran TT, Rogers MJ, Jessen N, et al. Skeletal muscle-selective

20 knockout of LKB1 increases insulin sensitivity, improves glucose homeostasis, and decreases

21 TRB3. Mol Cell Biol. 2006;26(22):8217-27. 
1 9. Gan B, Hu J, Jiang S, Liu Y, Sahin E, Zhuang L, et al. Lkb1 regulates quiescence and

2 metabolic homeostasis of haematopoietic stem cells. Nature. 2010;468(7324):701-4.

3 10. Gurumurthy S, Xie SZ, Alagesan B, Kim J, Yusuf RZ, Saez B, et al. The Lkb1 metabolic sensor

4 maintains haematopoietic stem cell survival. Nature. 2010;468(7324):659-63.

5 11. Ollila S, Makela TP. The tumor suppressor kinase LKB1: lessons from mouse models. J Mol

6 Cell Biol. 2011;3(6):330-40.

7 12. Guo JY, Karsli-Uzunbas G, Mathew R, Aisner SC, Kamphorst JJ, Strohecker AM, et al.

8 Autophagy suppresses progression of K-ras-induced lung tumors to oncocytomas and maintains

9 lipid homeostasis. Genes Dev. 2013;27(13):1447-61.

10 13. Guo JY, Teng X, Laddha SV, Ma S, Van Nostrand SC, Yang Y, et al. Autophagy provides

11 metabolic substrates to maintain energy charge and nucleotide pools in Ras-driven lung cancer

12 cells. Genes Dev. 2016;30(15):1704-17.

13 14. Komatsu M, Waguri S, Ueno T, Iwata J, Murata S, Tanida I, et al. Impairment of starvation-

14 induced and constitutive autophagy in Atg7-deficient mice. J Cell Biol. 2005;169(3):425-34.

15 15. Tsukada, M. and Ohsumi, Y, Isolation and characterization of autophagy-defective

16 mutants of Saccharomyces cervisiae. FEBS, 1993. 333(1,2): p. 169-174.

17 16. Karsli-Uzunbas G, Guo JY, Price S, Teng X, Laddha SV, Khor S, et al. Autophagy is required

18 for glucose homeostasis and lung tumor maintenance. Cancer Discov. 2014;4(8):914-27.

19 17. Ruzankina Y, Pinzon-Guzman C, Asare A, Ong T, Pontano L, Cotsarelis G, et al. Deletion of

20 the developmentally essential gene ATR in adult mice leads to age-related phenotypes and stem

21 cell loss. Cell Stem Cell. 2007;1(1):113-26. 
1 18. Lage R, Dieguez C, Vidal-Puig A, Lopez M. AMPK: a metabolic gauge regulating whole-body

2 energy homeostasis. Trends Mol Med. 2008;14(12):539-49.

3 19. Bhatt V, Khayati K, Hu ZS, Lee A, Kamran W, Su X, et al. Autophagy modulates lipid

4 metabolism to maintain metabolic flexibility for Lkb1-deficient Kras-driven lung tumorigenesis.

5 Genes Dev. 2019;33(3-4):150-65.

620 Eichner LJ, Brun SN, Herzig S, Young NP, Curtis SD, Shackelford DB, et al. Genetic Analysis

7 Reveals AMPK Is Required to Support Tumor Growth in Murine Kras-Dependent Lung Cancer

8 Models. Cell Metab. 2019;29(2):285-302 e7.

9 21. Hardie DG. Sensing of energy and nutrients by AMP-activated protein kinase. Am J Clin

10 Nutr. 2011;93(4):891S-6.

11 22. Sanders MJ, Grondin PO, Hegarty BD, Snowden MA, Carling D. Investigating the

12 mechanism for AMP activation of the AMP-activated protein kinase cascade. Biochem J.

$13 \quad 2007 ; 403(1): 139-48$.

14 23. Shan $T$, Xiong $Y$, Kuang S. Deletion of Lkb1 in adult mice results in body weight reduction

15 and lethality. Sci Rep. 2016;6:36561.

16 24. Gao Y, Yan Y, Tripathi S, Pentinmikko N, Amaral A, Päivinen P, et al. LKB1 Represses ATOH1

17 via PDK4 and Energy Metabolism and Regulates Intestinal Stem Cell Fate. Gastroenterology.

182020.

19 25. Shorning BY, Zabkiewicz J, McCarthy A, Pearson HB, Winton DJ, Sansom OJ, et al. Lkb1

20 deficiency alters goblet and paneth cell differentiation in the small intestine. PLoS One.

$212009 ; 4(1): e 4264$. 
1 26. Birchenough GM, Johansson ME, Gustafsson JK, Bergstrom JH, Hansson GC. New

2 developments in goblet cell mucus secretion and function. Mucosal Immunol. 2015;8(4):712-9.

3 27. Clevers H. The intestinal crypt, a prototype stem cell compartment. Cell. 2013;154(2):274-

484.

5 28. Wittkopf N, Gunther C, Martini E, Waldner M, Amann KU, Neurath MF, et al. Lack of

6 intestinal epithelial atg7 affects paneth cell granule formation but does not compromise immune

7 homeostasis in the gut. Clin Dev Immunol. 2012;2012:278059.

8 29. Blander JM. Death in the intestinal epithelium-basic biology and implications for

9 inflammatory bowel disease. FEBS J. 2016;283(14):2720-30.

10 30. Gunther C, Neumann H, Neurath MF, Becker C. Apoptosis, necrosis and necroptosis: cell

11 death regulation in the intestinal epithelium. Gut. 2013;62(7):1062-71.

12 31. Parker A, Maclaren OJ, Fletcher AG, Muraro D, Kreuzaler PA, Byrne HM, et al. Cell

13 proliferation within small intestinal crypts is the principal driving force for cell migration on villi.

14 FASEB J. 2017;31(2):636-49.

15 32. Liu X, Lu J, Liu Z, Zhao J, Sun H, Wu N, et al. Intestinal Epithelial Cell-Derived LKB1

16 Suppresses Colitogenic Microbiota. J Immunol. 2018;200(5):1889-900.

17 33. Trentesaux C, Fraudeau M, Pitasi CL, Lemarchand J, Jacques S, Duche A, et al. Essential 18 role for autophagy protein ATG7 in the maintenance of intestinal stem cell integrity. Proc Natl 19 Acad Sci U S A. 2020.

20 34. Cho EA, Lee DW, Cha YH, Lee SJ, Jung HC, Pan JG, et al. Characterization of a novel D-

21 lyxose isomerase from Cohnella laevoribosii RI-39 sp. nov. J Bacteriol. 2007;189(5):1655-63.

22 35. White E. Autophagy and p53. Cold Spring Harb Perspect Med. 2016;6(4):a026120. 
1 36. Yang Y, Karsli-Uzunbas G, Poillet-Perez L, Sawant A, Hu ZS, Zhao Y, et al. Autophagy

2 promotes mammalian survival by suppressing oxidative stress and p53. Genes Dev. 2020.

3 37. Udd L, Katajisto $\mathrm{P}$, Kyyronen M, Ristimaki AP, Makela TP. Impaired gastric gland

4 differentiation in Peutz-Jeghers syndrome. Am J Pathol. 2010;176(5):2467-76.

5 38. Gutierrez MG, Saka HA, Chinen I, Zoppino FC, Yoshimori T, Bocco JL, et al. Protective role

6 of autophagy against Vibrio cholerae cytolysin, a pore-forming toxin from V. cholerae. Proc Natl

$7 \quad$ Acad Sci U S A. 2007;104(6):1829-34.

8 39. Tan YK, Kusuma CM, St John LJ, Vu HA, Alibek K, Wu A. Induction of autophagy by anthrax

9 lethal toxin. Biochem Biophys Res Commun. 2009;379(2):293-7.

10 40. Terebiznik MR, Raju D, Vazquez CL, Torbricki K, Kulkarni R, Blanke SR, et al. Effect of

11 Helicobacter pylori's vacuolating cytotoxin on the autophagy pathway in gastric epithelial cells.

12 Autophagy. 2009;5(3):370-9. 
Figure Legends:

Fig 1. Autophagy is up-regulated in tissues of Lkb1-deficient mice.

a. Experimental design for generation of $A \operatorname{tg} 7^{-/-}, L k b 1^{-/-}$, and $A \operatorname{tg} 7^{-/-} ; L k b 1^{-/-}$mice.

b. Western blotting for Atg7 and Lkb1 of the indicated tissues from WT control, $A \operatorname{tg} 7^{-/-}, L k b 1^{-}$ /., and $\operatorname{Atg} 7^{-/} ; L k b 1^{-/}$adult mice. $\beta$-actin serves as a protein loading control.

C. Representative IHC for p62 of different tissues from WT control, $\operatorname{Atg} 7^{-/-}, L k b 1^{-/}$, and $\operatorname{Atg} 7^{-}$ /. $L k b 1^{-/}$adult mice.

d. Western blotting for p62, LC3I and LC3II from different tissues of WT control and Lkb1/mice with or without $\mathrm{HCQ}$ treatment represents the up-regulation of autophagy in $L k b 1$ deficient mice. $\beta$-actin serves as a protein loading control. Numbers indicate the quantification of protein levels normalized to actin and WT control.

Fig 2. Autophagy compensates for acute Lkb1 loss to support the survival of adult mice.

a. Kaplan-Meier survival curve of WT control, $\operatorname{Atg} 7^{-/}, L k b 1^{-/-}$, and $A \operatorname{tg} 7^{-/} ; L k b 1^{-/-}$adult mice. ${ }^{* * *} \mathrm{P}<0.001$, and ${ }^{* * * *} \mathrm{P}<0.0001$ (log-rank Mantel-Cox test).

b. Relative body weights of WT control, $\operatorname{Atg} 7^{-\alpha}, L k b 1^{-\alpha}$, and $\operatorname{Atg} 7^{-/} ; L k b 1^{-/}$adult mice normalized to the body weight of WT control mice. Data are mean \pm s.e.m. ${ }^{*} P<0.05$, *** $P<0.001$

Fig 3. Autophagy ablation deteriorates impaired intestinal structure and function caused by acute $L k b 1$ deletion

a. Representative H\&E staining of duodenum, jejunum, and ileum for WT control, Atg $^{-/}$, $L k b 1^{-/-}$and $A \operatorname{tg} 7^{-/-} ; L k b 1^{-/-}$adult mice.

b. Alcian blue staining of adult mouse intestine shows the enlargement of mucin-secreting cells in $L k b 1^{-/-}$and $A \operatorname{tg} 7^{-/-} ; L k b 1^{-/-}$mice. 
c. Representative IHC for intestinal lysozyme shows decrease of Paneth cell population in $L k b 1^{-/-}$and $A \operatorname{tg} 7^{-/-} ; L k b 1^{-/-}$crypts.

d. Representative IHC for OLFM4 of intestine shows the decrease of stem cells with greater extent in $A \operatorname{tg} 7^{-/-} ; L k b 1^{-/-}$crypts compared with WT control and $L k b 1^{-/-}$mice.

e. Left: Representative IHC for cleaved caspase-3 of intestine delineates increase of cell death in $A \operatorname{tg} 7^{-/-} ; L k b 1^{-/}$at tips of villi compared with WT control and $L k b 1^{-/-}$mice. Right: Quantification of cleaved caspase-3. Data are mean \pm s.e.m. ${ }^{*} \mathrm{P}<0.05$.

f. Representative relative FITC-dextran levels in sera of WT control, $\operatorname{Atg} 7^{-{ }^{--}}, L k b 1^{-/}$and $A \operatorname{tg} 7^{-/-} ; \mathrm{Lkb1} 1^{-/-}$adult mice at 4 hours post-oral gavage of FITC-dextran. Data are mean \pm s.e.m. ${ }^{*} \mathrm{P}<0.05,{ }^{* *} \mathrm{P}<0.01,{ }^{* *} \mathrm{P}<0.001$.

g. The level of serum D-lyxose in WT control, $A \operatorname{tg} 7^{--}, L k b 1^{1^{--}}$and $A \operatorname{tg} 7^{-/-} ; L k b 1^{-/}$adult mice measured by LC-MS shows an increase of D-lyxose in $A \operatorname{tg} 7^{-/-} ; \mathrm{Lkb} 1^{-/-}$sera compared with WT control mice. Data are mean \pm s.e.m. ${ }^{*} \mathrm{P}<0.05,{ }^{* *} \mathrm{P}<0.01$.

h. Kaplan-Meier survival curve of $\operatorname{Atg} 7^{-/} ; L k b 1^{-/}$mice treated without or with broadspectrum antibiotics (log-rank Mantel-Cox test).

i. Kaplan-Meier survival curve of $L k b 1^{-/}$mice treated without or with broad-spectrum antibiotics (log-rank Mantel-Cox test).

Fig 4. p53 deficiency extends the life span of $A \operatorname{tg} 7^{-/ /} ; L k b 1^{-/-}$mice.

a. Left: Representative IHC for p53 in different tissues of WT control, $\operatorname{Atg} 7^{-/}, L k b 11^{-/-}$and $\operatorname{Atg}^{-/-} ; L k b 1^{-/}$adult mice shows an increase of nuclear p53 in Atg7-ablated tissues. Right: Bar graphs represents the quantification of nuclear p53. Data are mean \pm s.e.m. ${ }^{*} \mathrm{P}<0.05,{ }^{* *} \mathrm{P}<0.01$, and ${ }^{* *} \mathrm{P}<0.001$.

b. Quantitative real-time PCR of Cdkn1a (p21) and PTEN for intestine tissues of WT control, $A \operatorname{tg} 7^{-/}, L k b 1^{-/}$and $A \operatorname{tg} 7^{-/} ; L k b 1^{-/}$adult mice. Data are mean \pm s.e.m. ${ }^{*} \mathrm{P}<0.05$, ${ }^{* * *} \mathrm{P}<0.001$, and ${ }^{* * *} \mathrm{P}<0.0001$. 
c. Kaplan-Meier survival curve of $L k b 1^{-/-}, \operatorname{Atg}^{-/-} ; L k b 1^{-/-}, L k b 1^{-/-} ; p 53^{-/}$and $\operatorname{Atg}^{-1 /} ; L k b 1^{-/-} ; p 53^{-}$ 1- adult mice. ${ }^{* * *} \mathrm{P}<0.001,{ }^{* * *} \mathrm{P}<0.0001$ and ns: non-significant (log-rank Mantel-Cox test).

Fig 5. Major metabolic pathways are disturbed in $L \mathrm{~kb} 1^{-/}$and $\operatorname{Atg}^{-/ /} ; \mathrm{Lkb1} 1^{-/-}$mice.

a. Left: Representative heat map of all the amino acids in sera of WT control, $\operatorname{Atg} 7^{-{ }^{-}}, L k b 1^{-}$ /- and $A \operatorname{tg} 7^{-/-} ; L k b 1^{-/-}$adult mice compared with WT control mice at fasting state. Right: Bar graphs show the levels of amino acids that are significantly decreased in $L k b 1^{-/}$and $\operatorname{Atg} 7^{-/} ; L k b 1^{-/}$mice sera compared with WT control mice. Data are mean \pm s.e.m. ${ }^{*} \mathrm{P}<0.05,{ }^{* *} \mathrm{P}<0.01,{ }^{* * *} \mathrm{P}<0.001$, and ${ }^{* * *} \mathrm{P}<0.0001$.

b-d Metabolites that are significantly decreased in the sera of $L k b 1^{-/-}$and $A \operatorname{tg} 7^{-/-} ; L k b 1^{-/}$mice compared with WT control mice at fasting state. Data are mean \pm s.e.m. ${ }^{*} \mathrm{P}<0.05$, ** $\mathrm{P}<0.01,{ }^{* * *} \mathrm{P}<0.001$ and ${ }^{* * * *} \mathrm{P}<0.0001$.

e. Relative blood glucose levels of WT control, $A \operatorname{tg} 7^{-/-}, L k b 1^{-/-}$and $A \operatorname{tg} 7^{-/} ; L k b 1^{-/-}$adult mice normalized to WT control mice at fed state for the indicated time course after first TAM injection. Data are mean \pm s.e.m. ${ }^{*} \mathrm{P}<0.05$.

f. Quantification of serum insulin levels of WT control, $\operatorname{Atg} 7^{-/-}, L k b 1^{-/-}$and $A \operatorname{tg} 7^{-/-} ; L k b 1^{-/}$adult mice at fasted state at 10 days post deletion. Data are mean \pm s.e.m. ${ }^{*} \mathrm{P}<0.05,{ }^{* *} \mathrm{P}<0.01$, ns: non-significant.

Fig 6. Mechanism by which Lkb1 interacts with autophagy to support adult mice homeostasis and survival

Loss of Lkb1 causes hypoglycemia, impaired intestinal epithelium barrier integrity, increased general infection, and disturbed host sera metabolism. When autophagy is intact, these dysfunctions are temporarily compensated by autophagy upregulation, partly 
bioRxiv preprint doi: https://doi.org/10.1101/2020.08.26.268003; this version posted August 26, 2020. The copyright holder for this preprint

(which was not certified by peer review) is the author/funder, who has granted bioRxiv a license to display the preprint in perpetuity. It is made available under aCC-BY 4.0 International license.

through preventing p53 activation. However, autophagy deficiency further exacerbates the dysfunctions induced by $L k b 1$ deletion, thereby accelerating mouse death. 
bioRxiv preprint doi: https://doi.org/10.1101/2020.08.26.268003; this version posted August 26, 2020. The copyright holder for this preprint (which was not certified by peer review) is the author/funder, who has granted bioRxiv a license to display the preprint in perpetuity. It is made available under aCC-BY 4.0 International license.

Fig. 1

8-10 week old

Ubc-CreERT2/+

Ubc-CreERT2/+; Atg $7^{\text {flox/flox }}$

Ubc-CreERT2/+: Lkb1 $1^{\text {flox/flox }}$

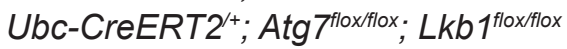

Tissue homeostasis??

Survival??
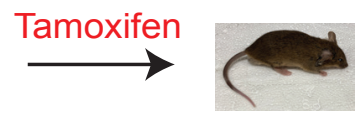

Wild Type

Atg $7^{-/-}$

$L k b 1^{-1}$

$\operatorname{Atg} 7^{-/-} ; L k b 1^{-/-}$ b

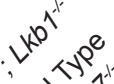

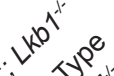

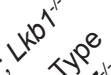

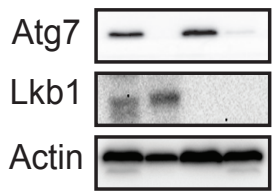

Actin
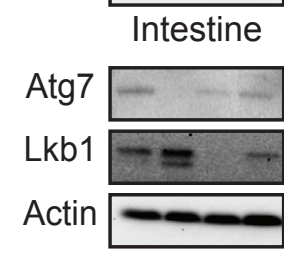

Muscle

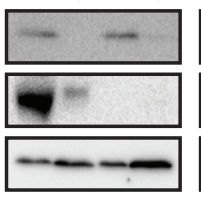

Liver

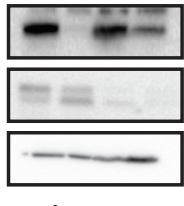

Lung

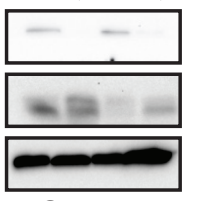

Spleen

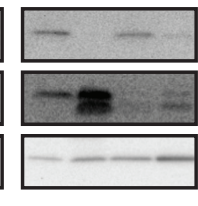

Pancreas
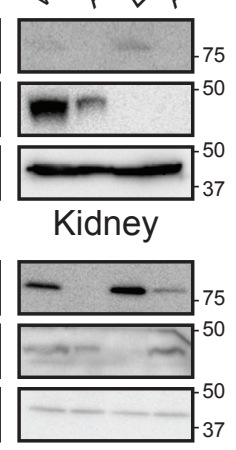

Brain

p62

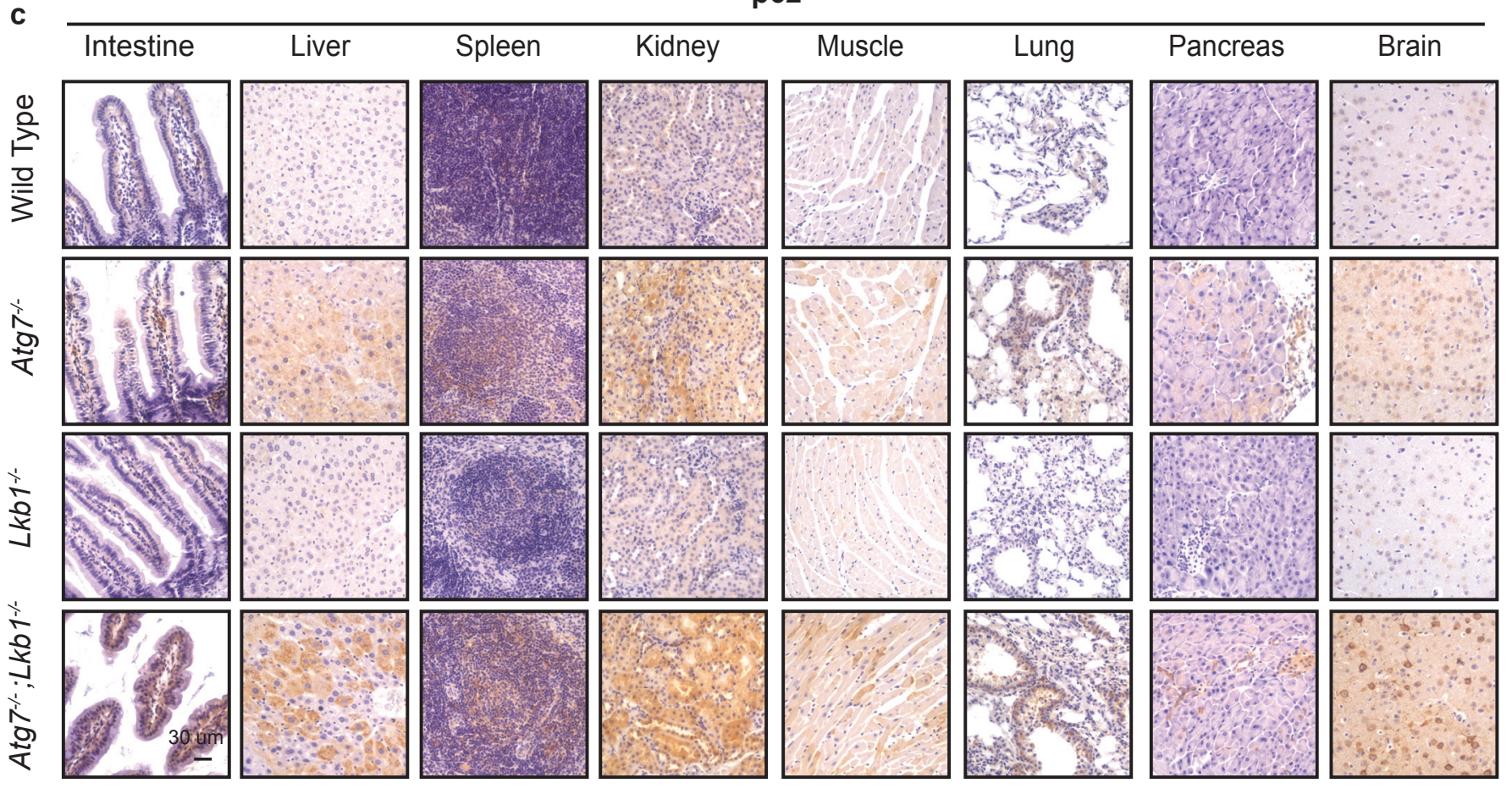

d

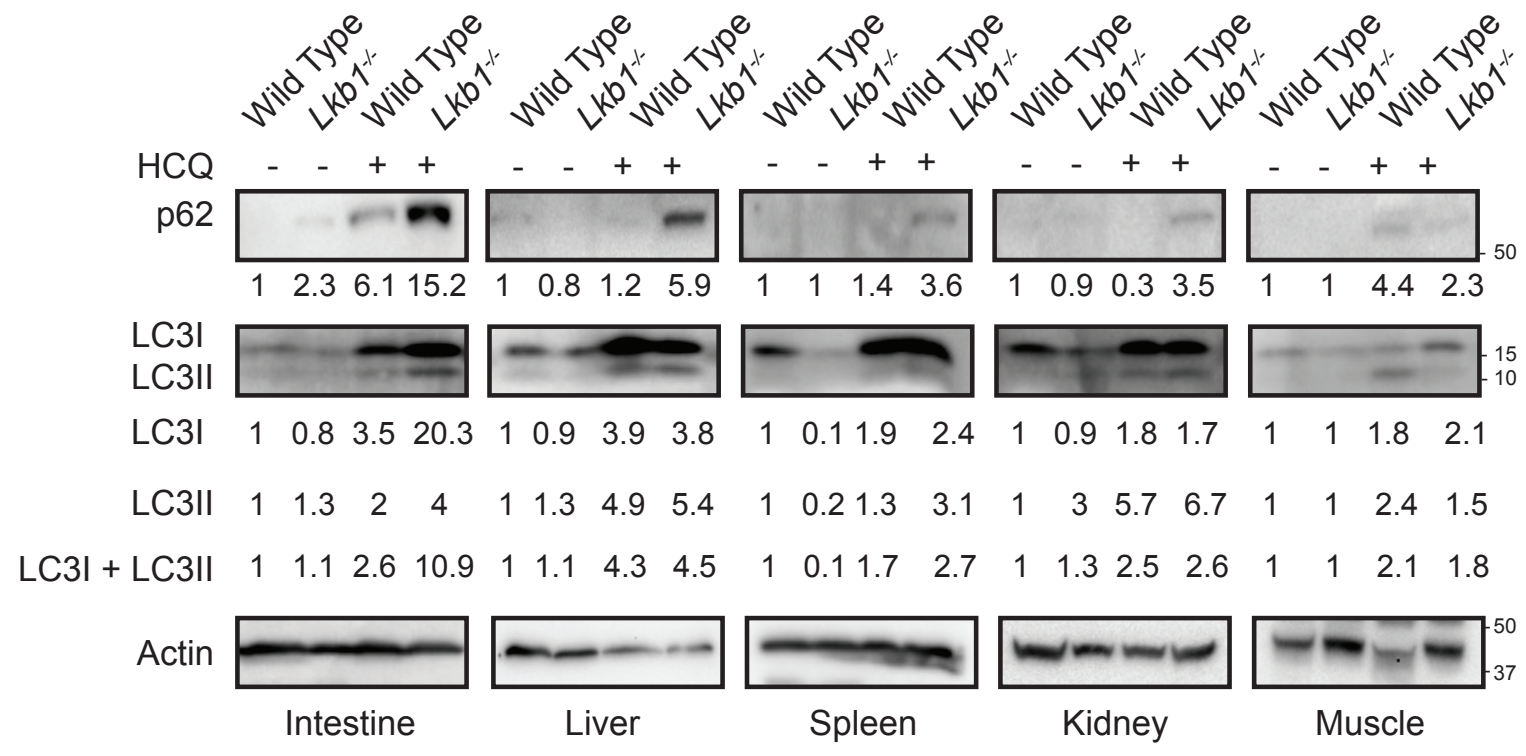


bioRxiv preprint doi: https://doi.org/10.1101/2020.08.26.268003; this version posted August 26, 2020. The copyright holder for this preprint (which was not certified by peer review) is the author/funder, who has granted bioRxiv a license to display the preprint in perpetuity. It is made available under aCC-BY 4.0 International license.

Fig. 2
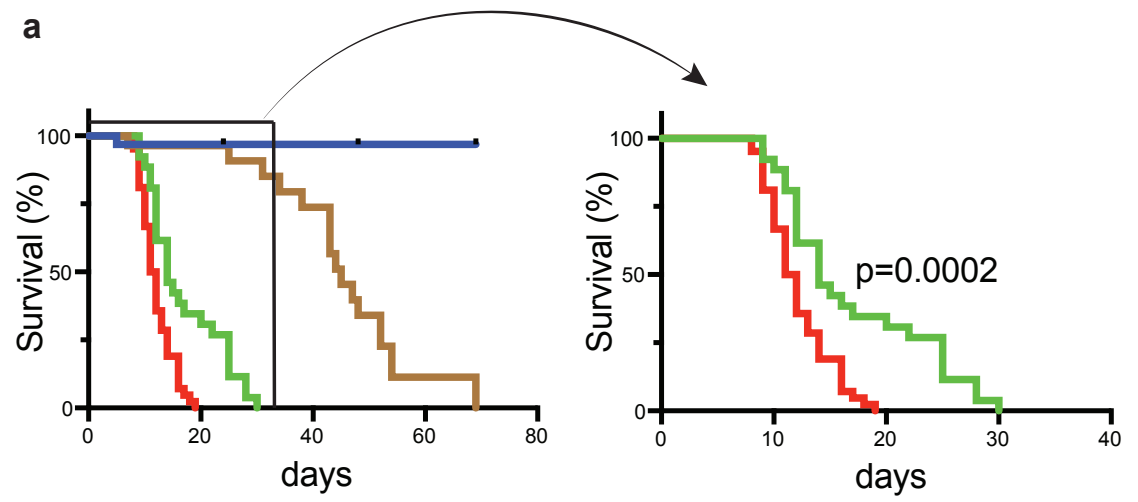

- Wild Type ( $n=32)$

- $\operatorname{Atg}^{-1-}(\mathrm{n}=28)$

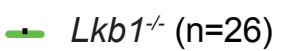

- $\operatorname{Atg}^{-\sim} ; \operatorname{Lkb1}^{-\sim}(\mathrm{n}=42)$

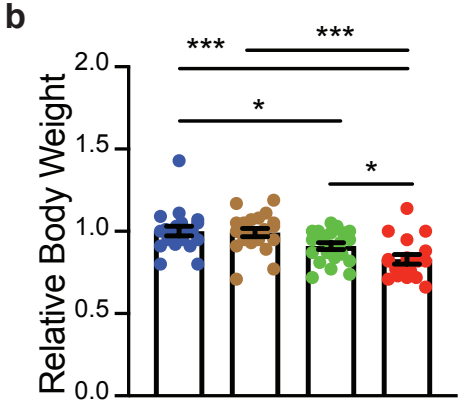

- Wild Type $(n=20)$

- $\operatorname{Atg} 7^{-1-}(\mathrm{n}=21)$

- $L k b 1^{-1}(\mathrm{n}=22)$

- $\operatorname{Atg} 7^{-\sim} ; L k b 1^{-\sim}(\mathrm{n}=18)$ 
bioRxiv preprint doi: https://doi.org/10.1101/2020.08.26.268003; this version posted August 26, 2020. The copyright holder for this preprint

(which was not certified by peer review) is the author/funder, who has granted bioRxiv a license to display the preprint in perpetuity. It is made available under aCC-BY 4.0 International license.

Fig. 3
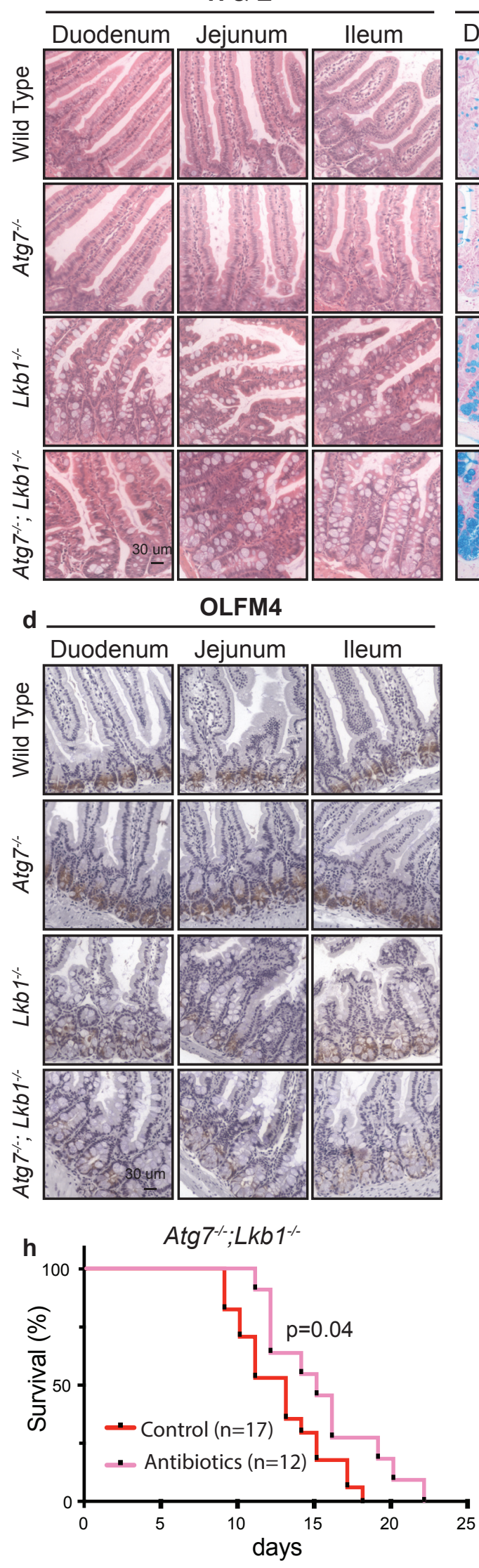

b

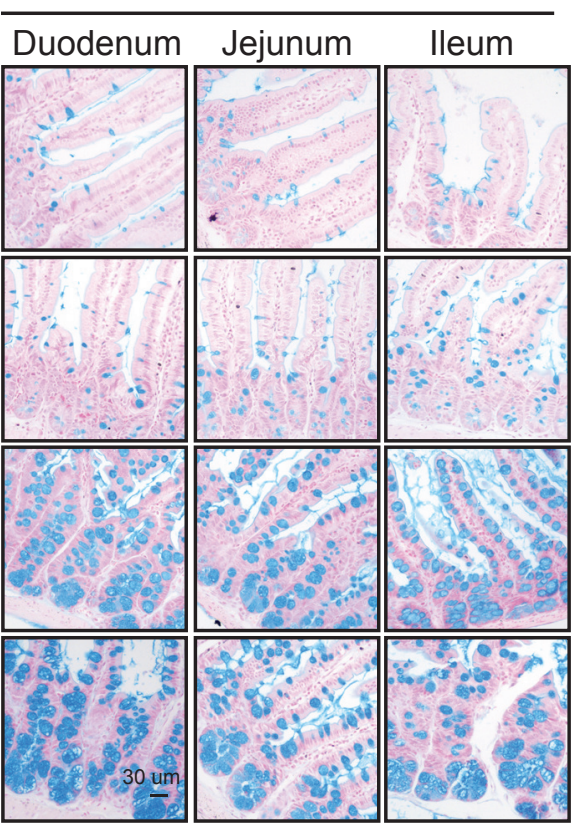

e Cleaved Caspase-3
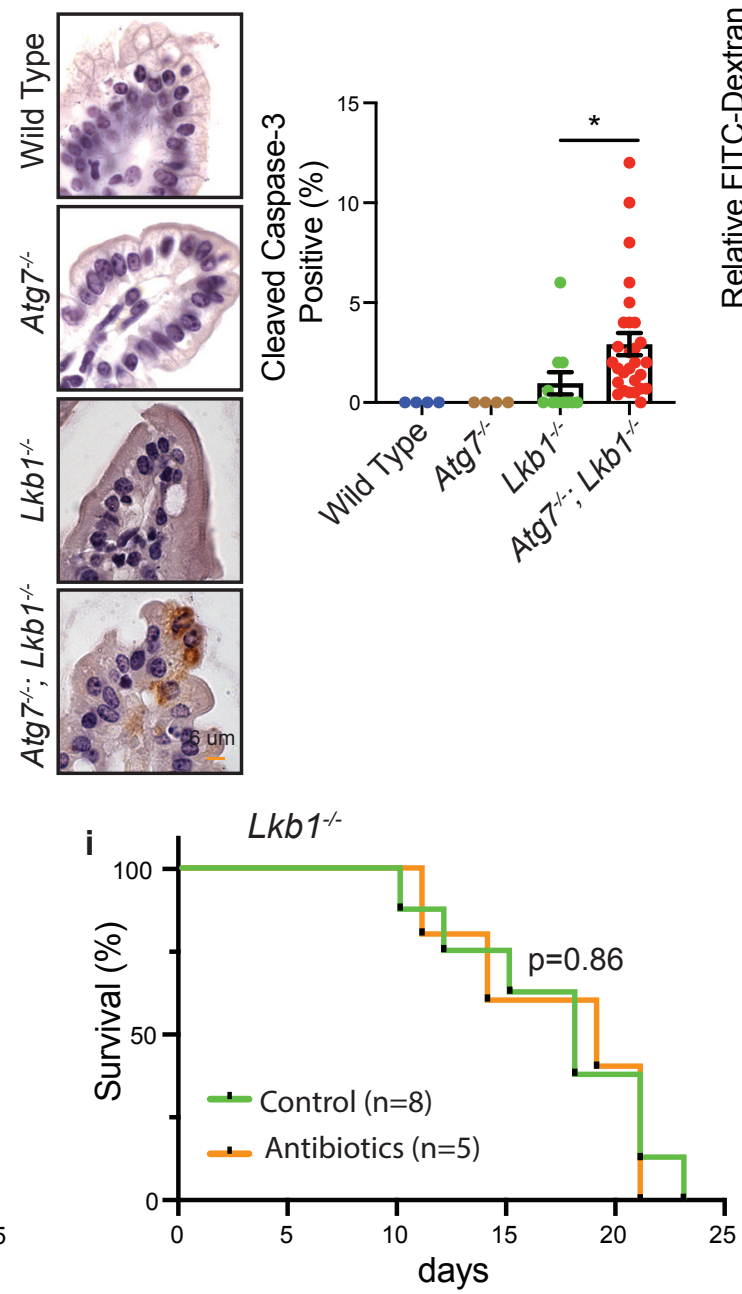

Lysozyme

Duodenum Jejunum lleum
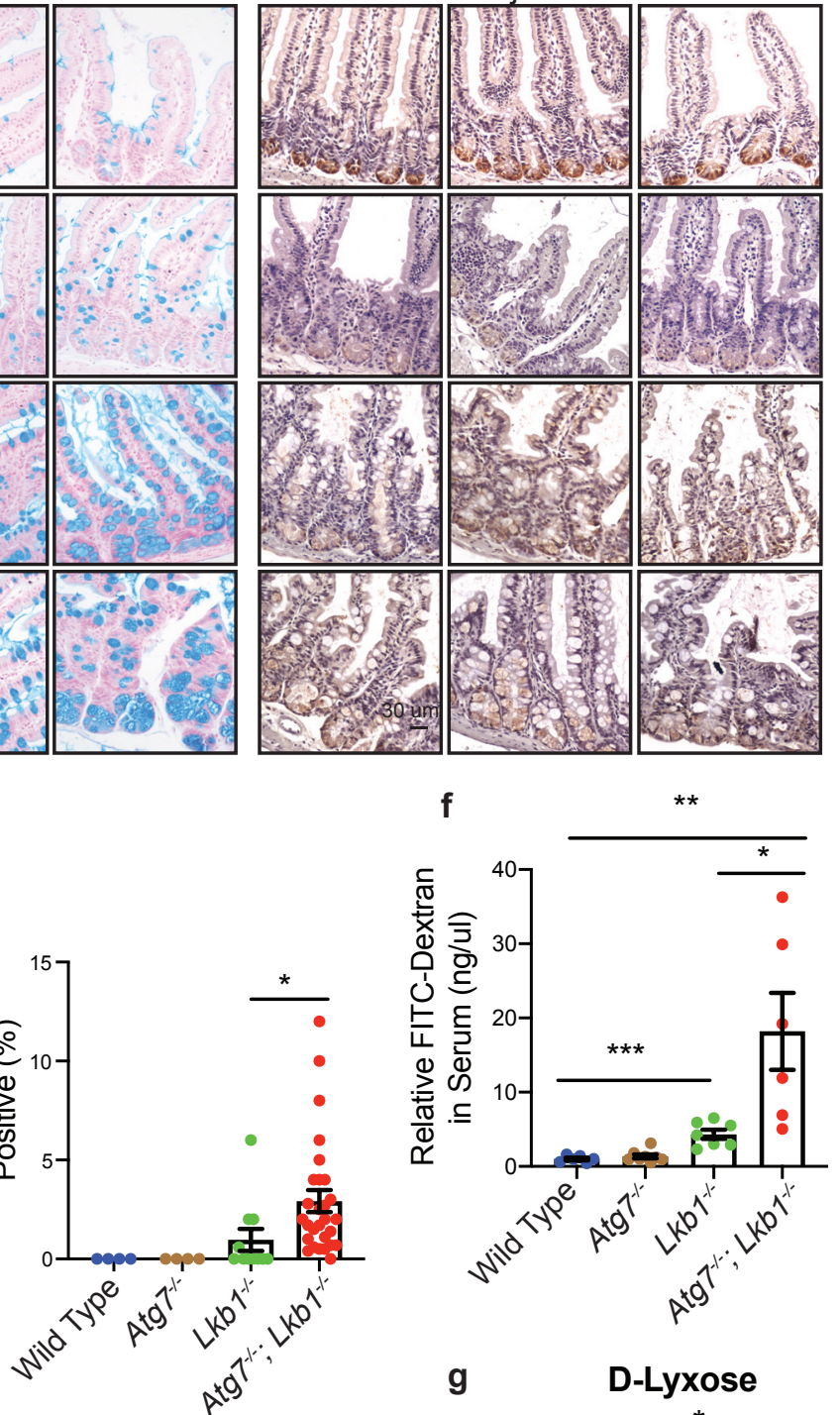

g

D-Lyxose

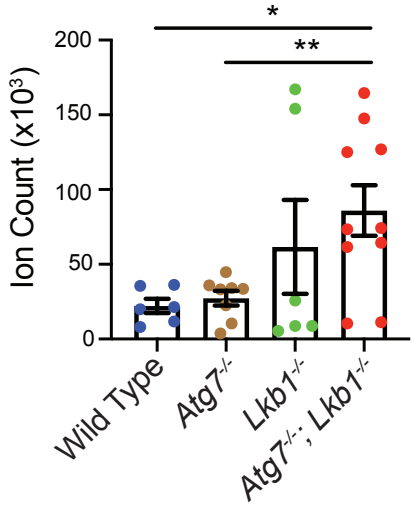


bioRxiv preprint doi: https://doi.org/10.1101/2020.08.26.268003; this version posted August 26, 2020. The copyright holder for this preprint (which was not certified by peer review) is the author/funder, who has granted bioRxiv a license to display the preprint in perpetuity. It is made available under aCC-BY 4.0 International license.

Fig. 4

a

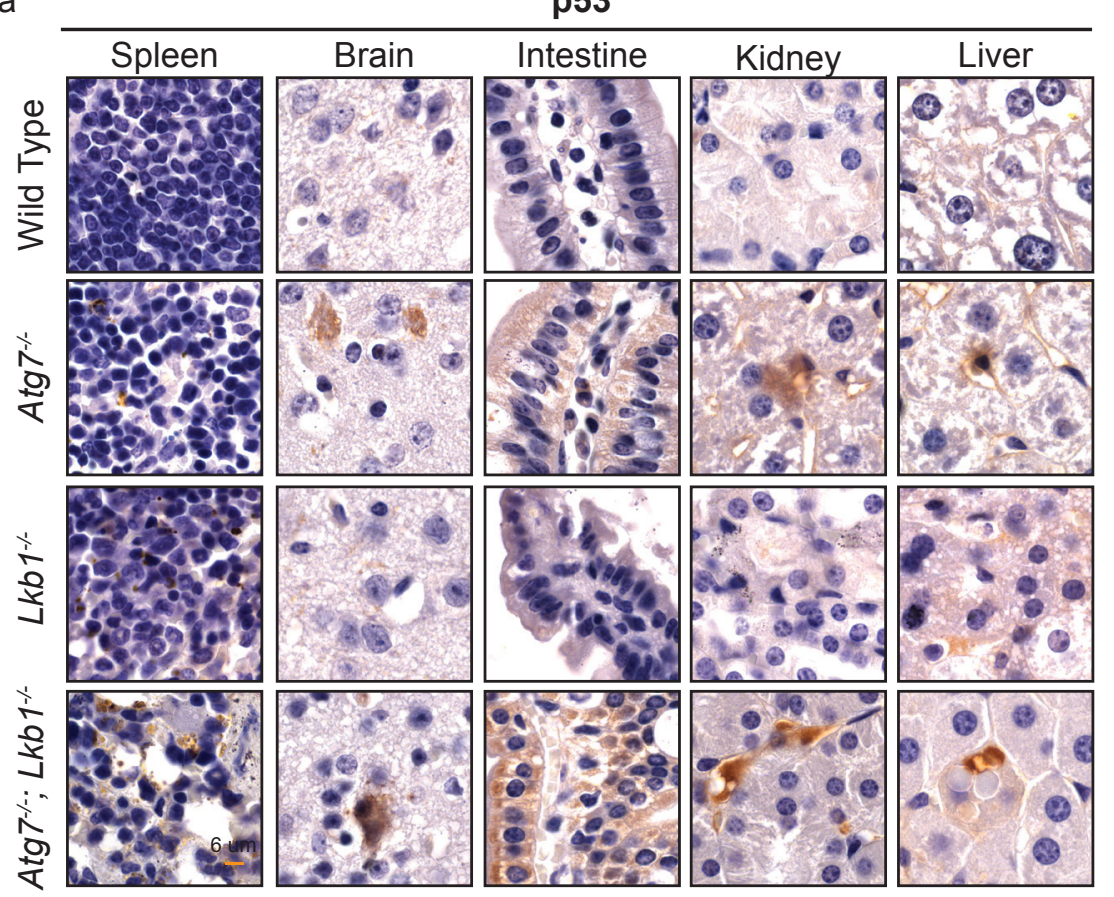

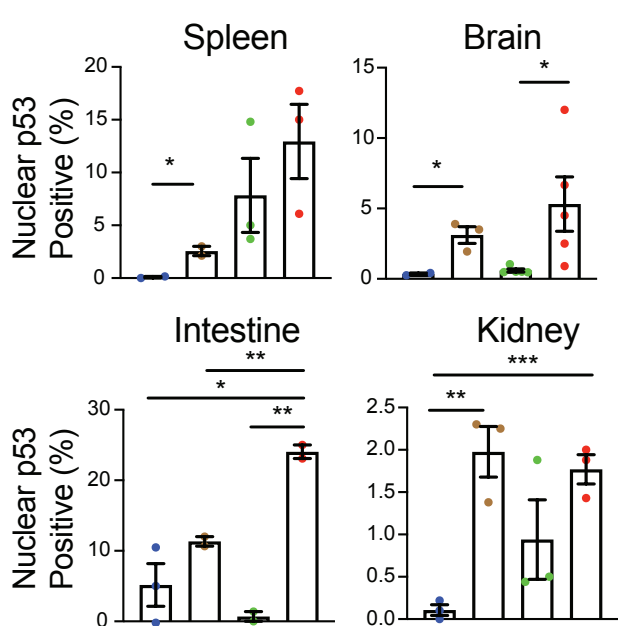

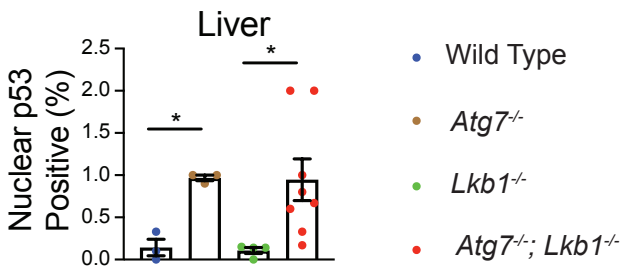

b

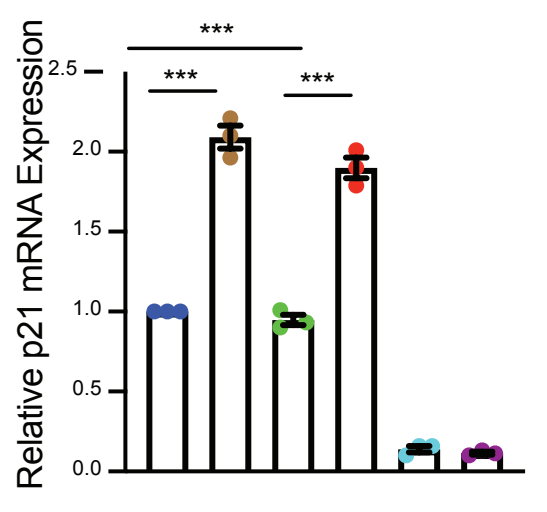

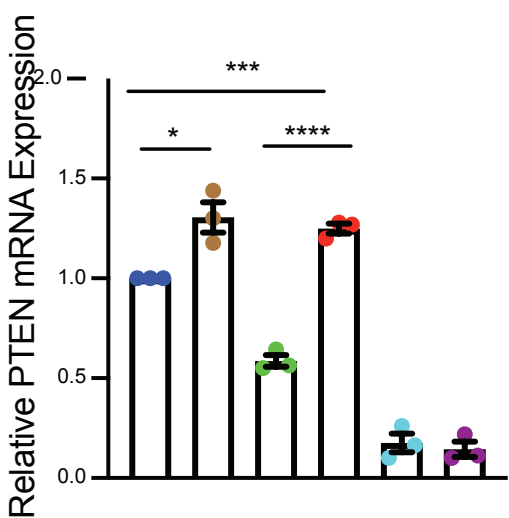

C

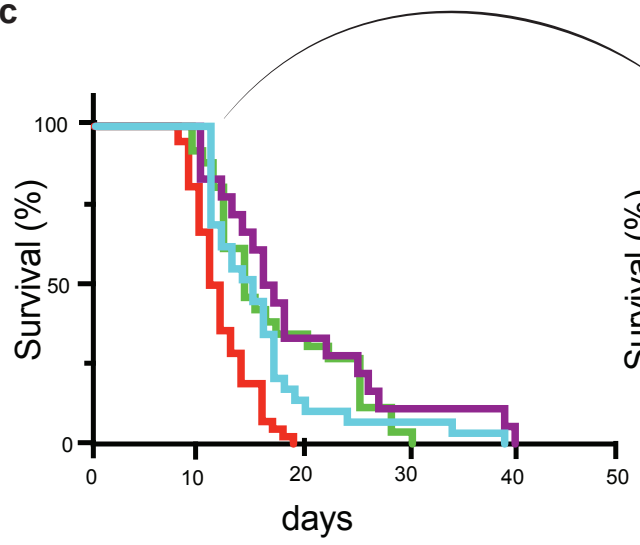

- Wild Type

- $\operatorname{Atg} 7^{-1-}$

- $L k b 1^{-1-}$

- $\operatorname{Atg} 7^{-/} ; \operatorname{Lkb} 1^{--}$

- $L k b 1^{-\sim} ; p 53^{--}$

- $\operatorname{Atg} 7^{-\cdots}, \operatorname{Lkb} 1^{\varkappa} ; p 53^{--}$

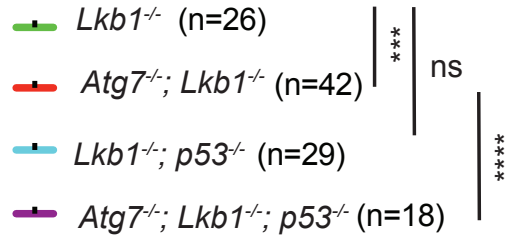


bioRxiv preprint doi: https://doi.org/10.1101/2020.08.26.268003; this version posted August 26, 2020. The copyright holder for this preprint (which was not certified by peer review) is the author/funder, who has granted bioRxiv a license to display the preprint in perpetuity. It is made available under aCC-BY 4.0 International license.

Fig. 5

\section{a Amino acid heatmap}
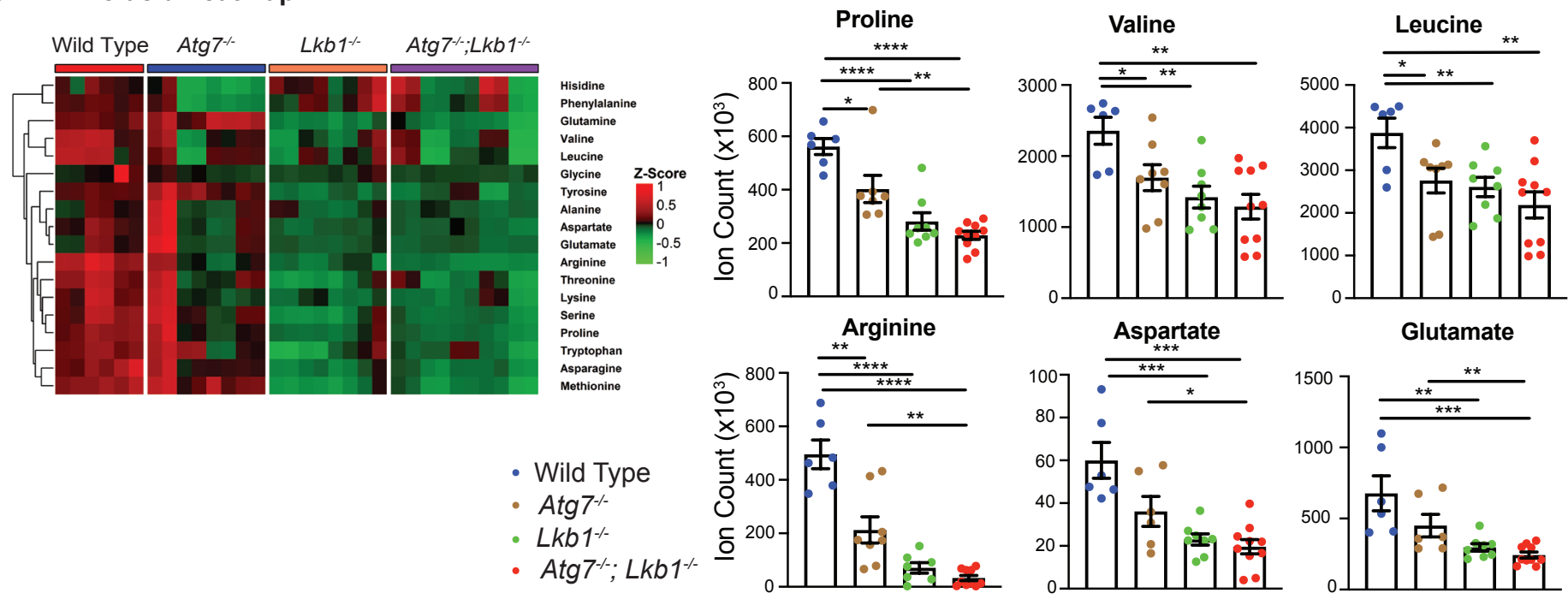

b TCA-cycle metabolites

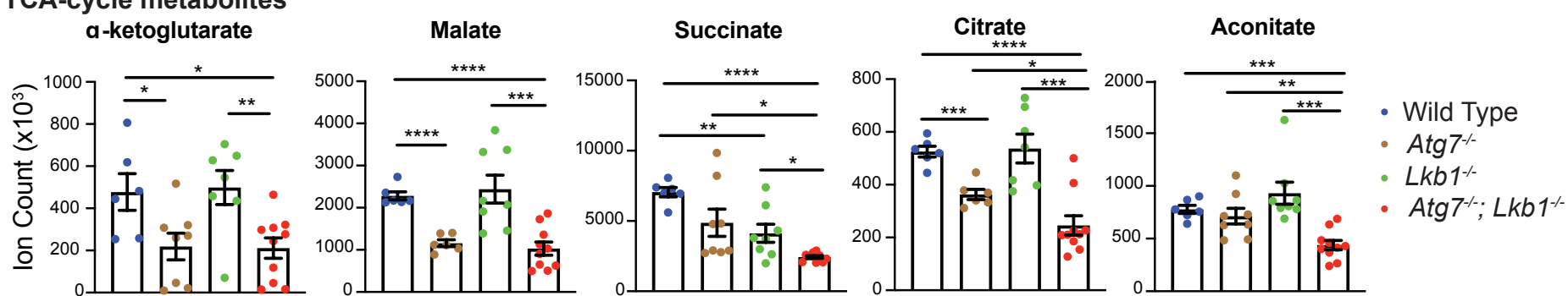

c Urea cycle metabolites Citrulline

d Glycolysis pathway metabolites

- - $\operatorname{tg} 7^{-/}$
-

- $L k b 1^{-\alpha}$

- $\operatorname{Atg} 7^{-\%}, L k b 1^{\varkappa}$
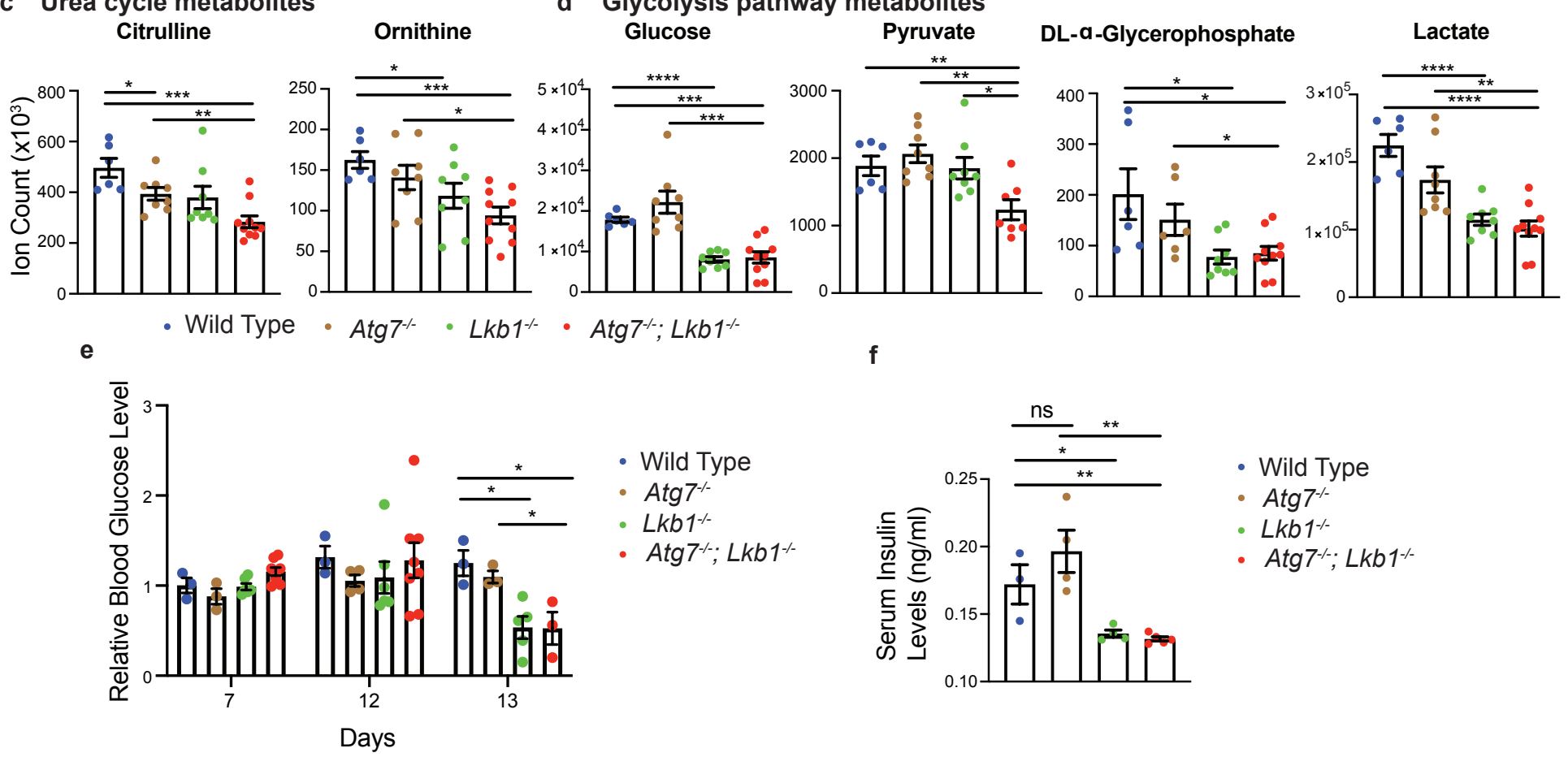
bioRxiv preprint doi: https://doi.org/10.1101/2020.08.26.268003; this version posted August 26, 2020. The copyright holder for this preprint (which was not certified by peer review) is the author/funder, who has granted bioRxiv a license to display the preprint in perpetuity. It is made available under aCC-BY 4.0 International license.

Fig. 6
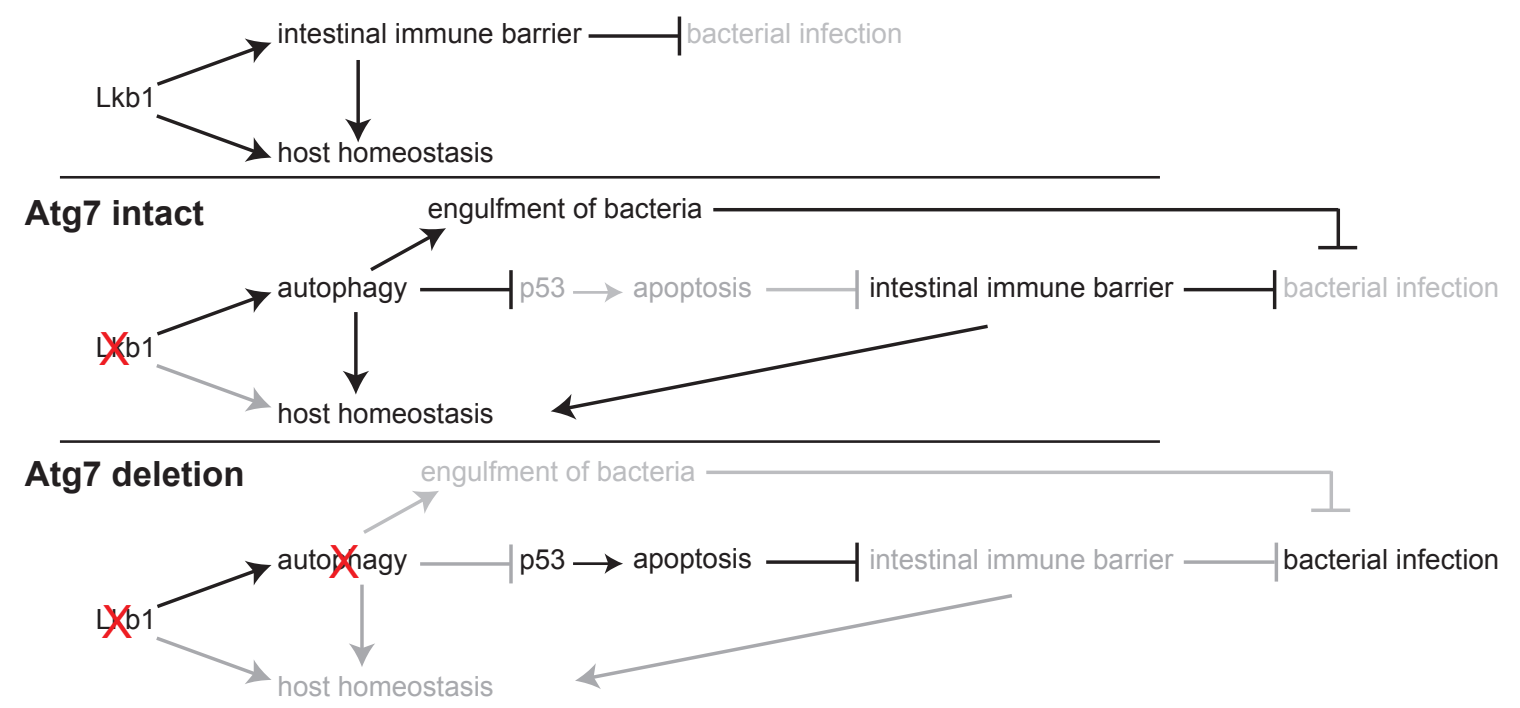


\section{Supplementary figures:}

Fig S1. Autophagy and Lkb1 inhibitions do not lead to pancytopenia.

Quantification of red blood cells, white blood cells, and platelets of WT control, $\operatorname{Atg}^{-{ }^{--}}, L_{k b 1}{ }^{-}$ '-, and $\operatorname{Atg} 7^{-/} ; L k b 1^{-/}$adult mice. Data are mean \pm s.e.m. ${ }^{*} \mathrm{P}<0.05$, ns: non-significant.

Fig S2. The histology of most mouse tissues and intestinal cell proliferation are not impacted by short-term deletion of Atg7 and Lkb1.

a. Representative brain, heart, kidney, liver, lung, muscle, pancreas, and spleen histology (H\&E staining) of WT control, $\operatorname{Atg} 7^{-/-}, L k b 1^{-/-}$, and $\operatorname{Atg} 7^{-/-} ; L k b 1^{--}$adult mice.

b. Representative IHC for Atg7 and Lkb1 from intestine of WT control, $A \operatorname{tg} 7^{-/}, L k b 1^{-/-}$and $\operatorname{Atg} 7^{-/} ; L k b 1^{-/}$adult mice.

c. Representative IHC for LC3 from intestine of WT control, $\operatorname{Atg} 7^{-/}, L k b 1^{-/-}$and $A \operatorname{tg} 7^{-/} ; L k b 1^{-}$ /- adult mice shows accumulation of LC3II puncta (arrows) in Lkb1-deficient mice.

d. Representative IHC for Ki67 from intestine of WT control, $\operatorname{Atg} 7^{-/}, L k b 1^{-/-}$and $A \operatorname{tg} 7^{-/} ; L k b 1^{-}$ '- adult mice shows no significant difference in the rate of proliferation within the groups.

Fig S3. p53 is activated in the absence of autophagy.

Representative IHC of p53 with lower magnification in brain, heart, intestine, kidney, liver, muscle and spleen of WT control, $\operatorname{Atg} 7^{-/}, L k b 1^{-/}$, and $\operatorname{Atg} 7^{-/} ; L k b 1^{-/}$adult mice shows the increase of nuclear p53 in Atg7-ablated tissues.

Fig S4. Acute loss of Lkb1 alone or together with Atg7 altered the levels of metabolites in intestine.

a-d Metabolites that are significantly decreased in the intestine of $L k b 1^{-/-}$and $A \operatorname{tg} 7^{-/-}, L k b 1^{-/}$mice compared with WT control mice. Data are mean \pm s.e.m. ${ }^{*} P<0.05,{ }^{* *} P<0.01,{ }^{* *} P<0.001$, $* * * * P<0.0001$. 
bioRxiv preprint doi: https://doi.org/10.1101/2020.08.26.268003; this version posted August 26, 2020. The copyright holder for this preprint (which was not certified by peer review) is the author/funder, who has granted bioRxiv a license to display the preprint in perpetuity. It is made available under aCC-BY 4.0 International license.

Sup. Fig. 1

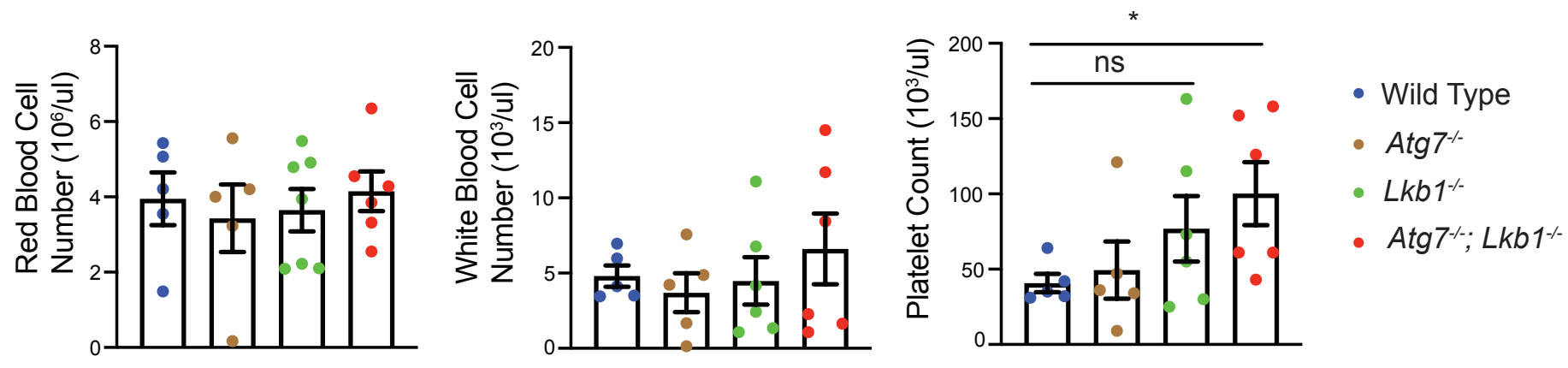


bioRxiv preprint doi: https://doi.org/10.1101/2020.08.26.268003; this version posted August 26, 2020. The copyright holder for this preprint

(which was not certified by peer review) is the author/funder, who has granted bioRxiv a license to display the preprint in perpetuity. It is made available under aCC-BY 4.0 International license.

Sup. Fig. 2
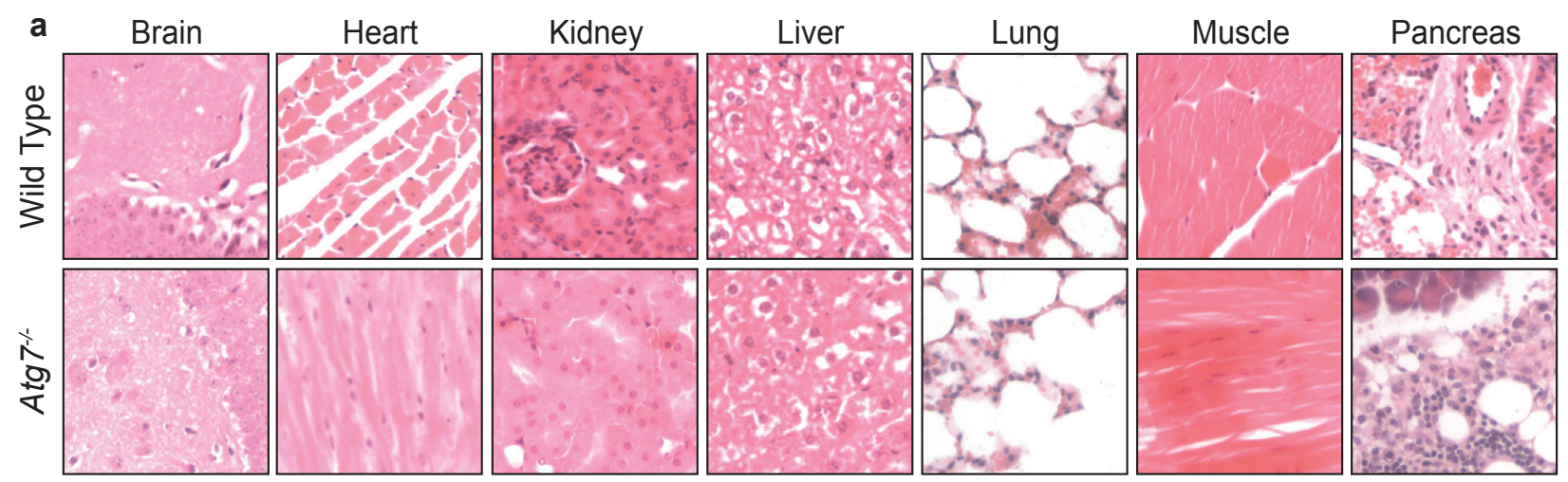

Spleen
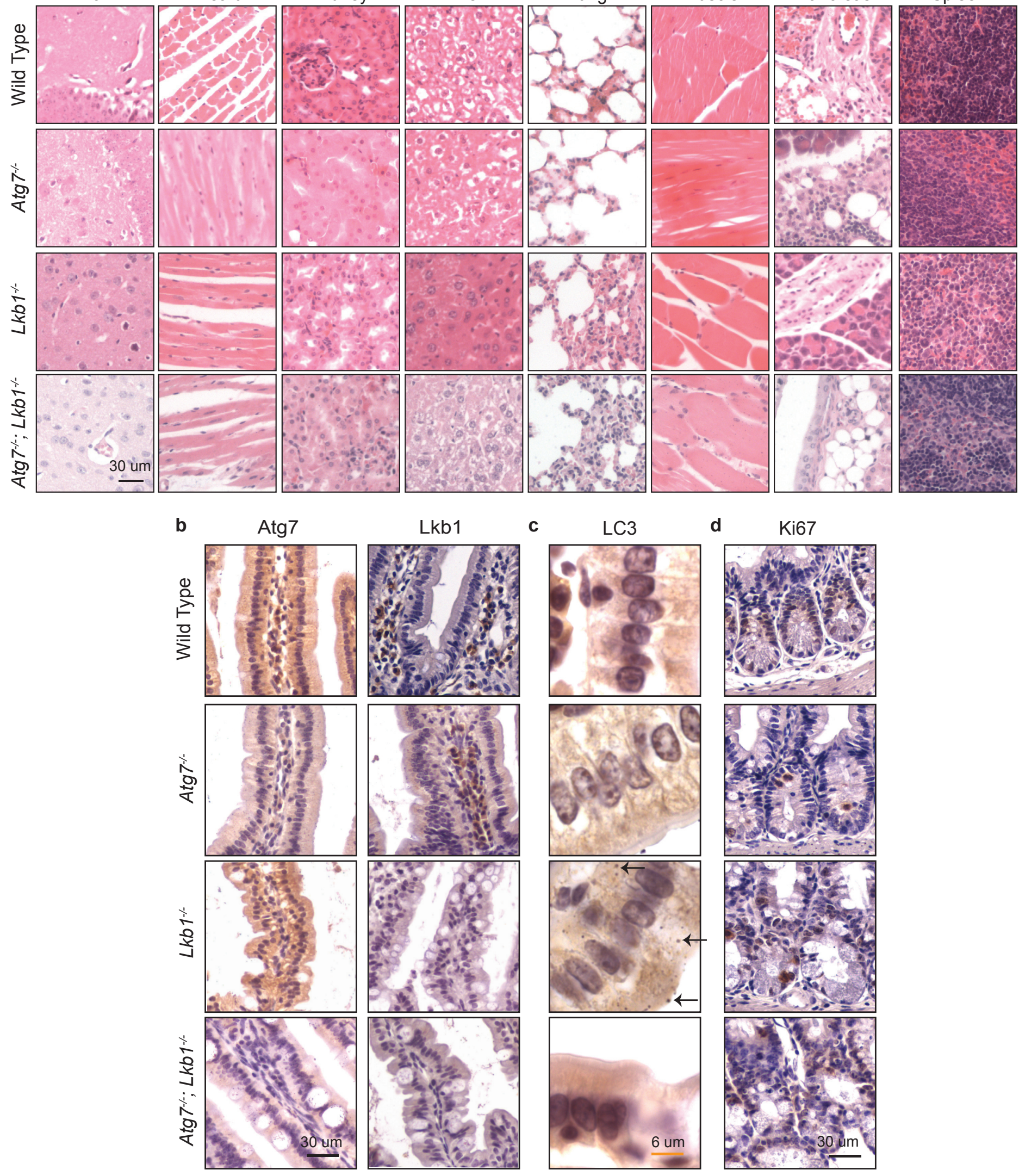
bioRxiv preprint doi: https://doi.org/10.1101/2020.08.26.268003; this version posted August 26, 2020. The copyright holder for this preprint (which was not certified by peer review) is the author/funder, who has granted bioRxiv a license to display the preprint in perpetuity. It is made available under aCC-BY 4.0 International license.

Sup. Fig. 3

p53

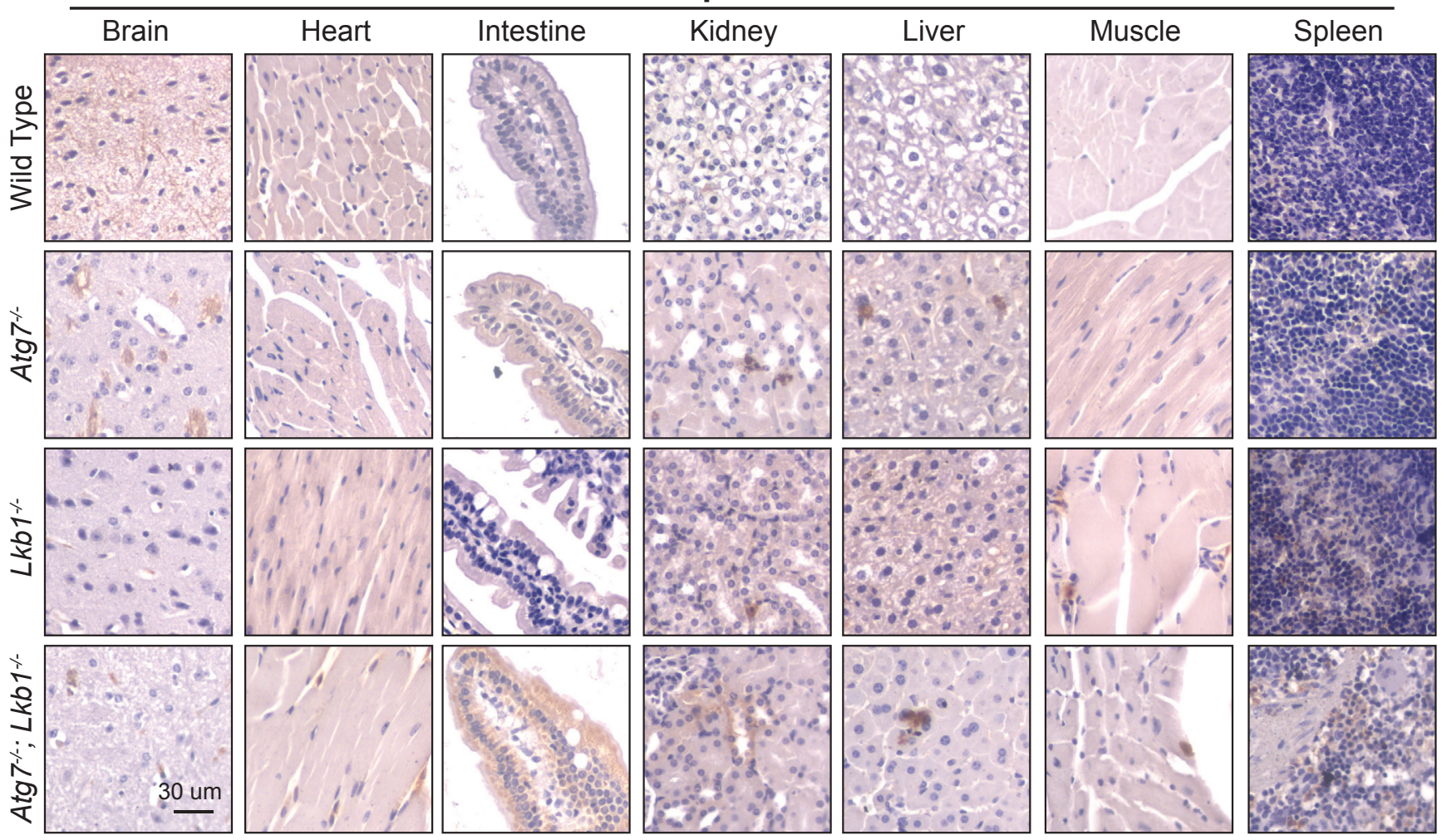


bioRxiv preprint doi: https://doi.org/10.1101/2020 08.26.268003; this version posted August 26, 2020. The copyright holder for this preprint (which was not certified by peer review) is the author/funder, who has granted bioRxiv a license to display the preprint in perpetuity. It is made available under aCC-BY 4.0 International license.

Sup. Fig. 4

a Intestine amino acids

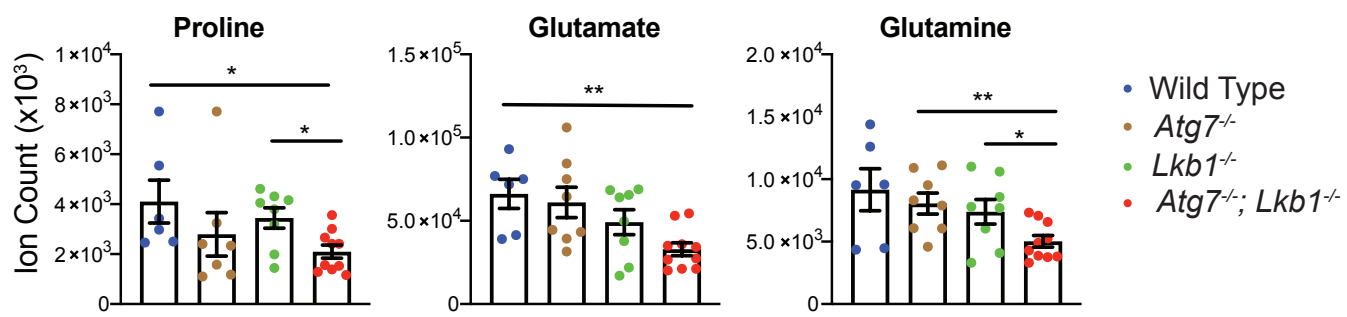

b Intestine TCA-cycle metabolites c Intestine urea cycle metabolites
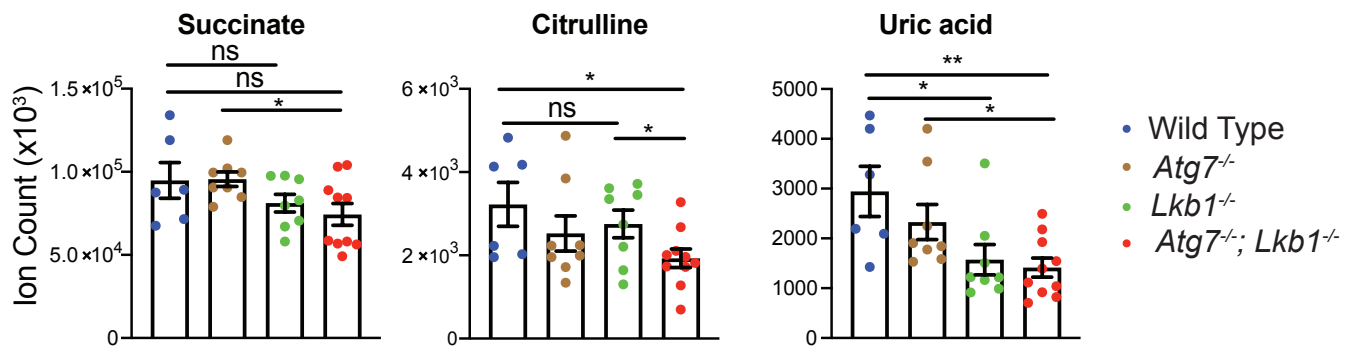

d Intestine glycolysis pathway metabolites
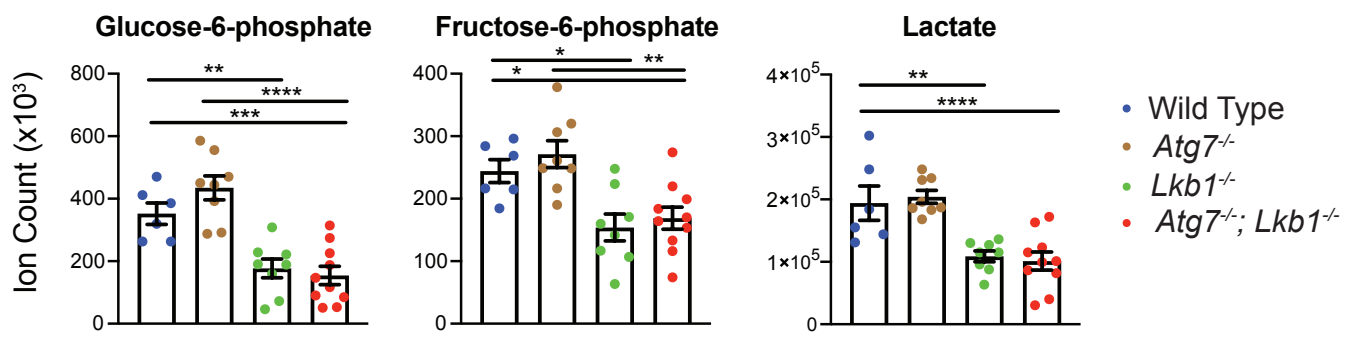